Feature 15

Feature 15 is the concrete foundation for the Experimenters Handling and Dry Storage building (Building 12-899) (Figure 74). The foundation measures $92 \mathrm{ft}(28 \mathrm{~m})$ north-south by $20 \mathrm{ft} 4$ inches east-west and is up to 24 inches thick. A 2-inch angle iron frame surrounds the top perimeter edge of the concrete. Along the north end of the foundation is a $20 \mathrm{ft}$ north-south by $20 \mathrm{ft} 4 \mathrm{inch}$ ramp that was constructed separately from the foundation. Equipment stored on the south end of the foundation is an electrical panel box and four automatic electrical switches. Feature 15 is 18 inches east of existing rails that extend from the U12t Tunnel portal. Artifacts near the feature are metal fragments, electrical switches, insulated wire and cable, and a broom.

Feature 16

Feature 16 is a concrete and metal underground access (Figure 75). The access consists of a $5 \mathrm{ft} 6$ inch $x 5 \mathrm{ft} 6$ inch $(1.7 \times 1.7 \mathrm{~m})$ subterranean concrete box with a metal cover. The exposed rim of the box is 4 inches wide and flush with the surface. The metal cover is $4 \mathrm{ft} 10$ inches $\mathrm{x} 4 \mathrm{ft} 10$ inches $(1.47 \times 1.47 \mathrm{~m})$ and is approximately $3 / 8$ inches $(1 \mathrm{~cm})$ thick and recessed flush with the top edge of the concrete box. The feature is possibly part of an underground drainage system (Wayne Griffin, Larry Ashbaugh, and Byron Ristvet 2007, personal communication). No attempt was made to open the metal cover.

Feature 17

Feature 17 is a concrete foundation for a LIN Cooling System and Haliburton Yard (Figure 76). The LIN (Liquid Nitrogen) Cooling System solidifies concrete with liquid nitrogen without a chemical reaction. The foundation measures $36 \mathrm{ft}(11 \mathrm{~m})$ east-west by $12 \mathrm{ft}$ north-south and is 20 inches $(51$ $\mathrm{cm})$ thick. Protruding through the surface are $13 / 8$ inch $(3.5 \mathrm{~cm})$ bolts and $8 \times 8$ inch metal plates. Artifacts near the feature are metal plates, bolts, and electrical conduit.

\title{
Feature 18
}

Feature 18 is a concrete foundation for a LIN Cooling System and Haliburton Yard (similar function as Feature 17) (Figure 77). The foundation is $13 \times 13 \mathrm{ft}$ and is 6 inches thick. A $1 / 4$ inch recess along the top perimeter edge of the concrete indicates the location of a bottom plate for a wall of a building. Artifacts near the feature are bolts, nuts, electrical conduit and metal strapping.

\section{Feature 19}

Feature 19 is a concrete pad for an Electrical Substation (Figure 78). The pad measures $11 \mathrm{ft} 6$ inches by $11 \mathrm{ft} 6$ inches $(3.5 \times 3.5 \mathrm{~m})$ and is 6 inches thick. A rust impression along the south edge indicates an object, possibly a transformer or switch box, $58 \times 36$ inches $(147.3 \times 91.4 \mathrm{~cm})$ was supported on the pad. A second impression along the west edge is $43 \times 12$ inches $(109.2 \times 30.5 \mathrm{~cm})$ and possibly indicates the location of a panel box. Conduit extends through the surface and is $31 / 2(8.9 \mathrm{~cm})$ and 

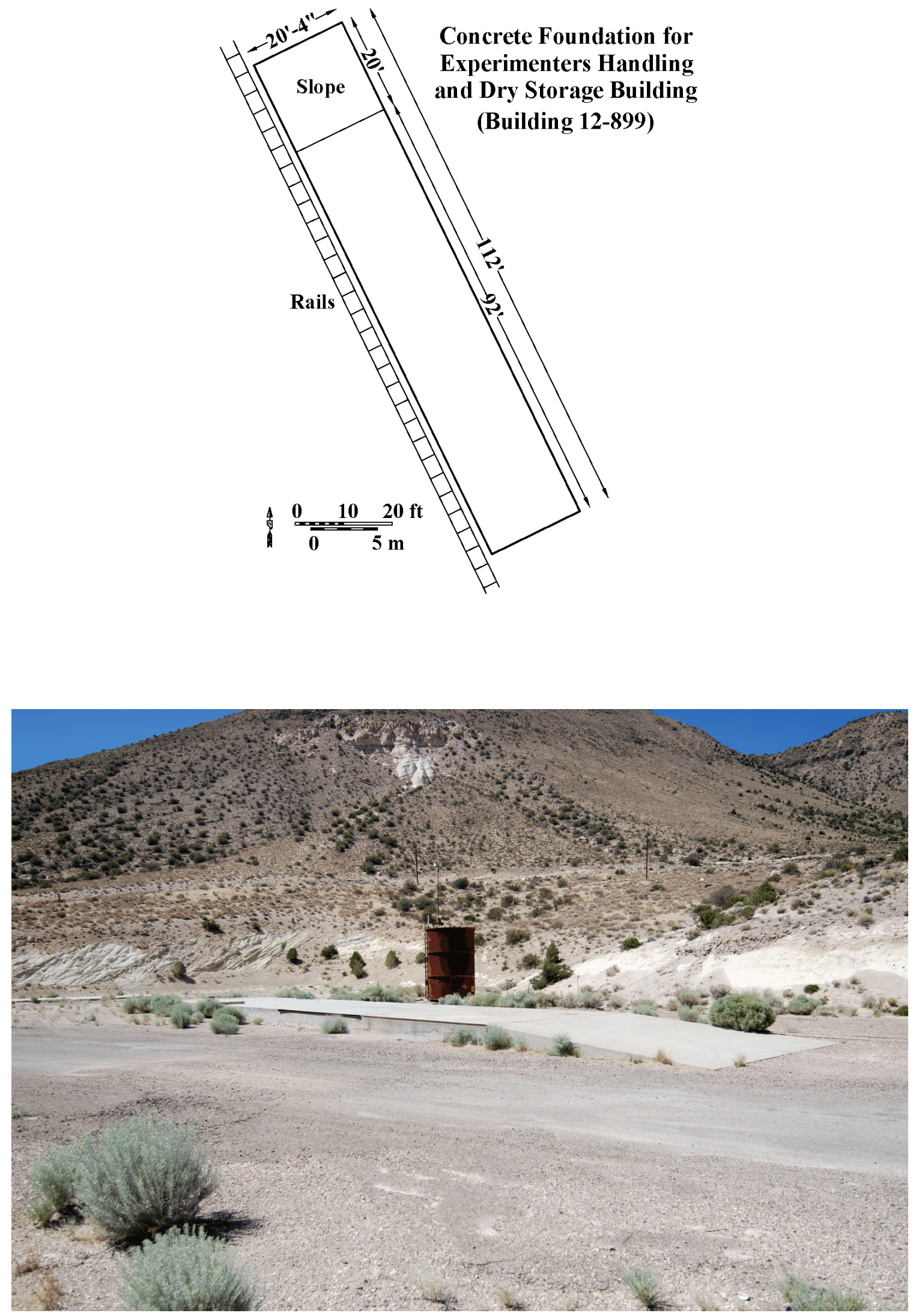

Figure 74. Plan map and photograph of Feature 15, U12t Tunnel, view southwest (2007). 

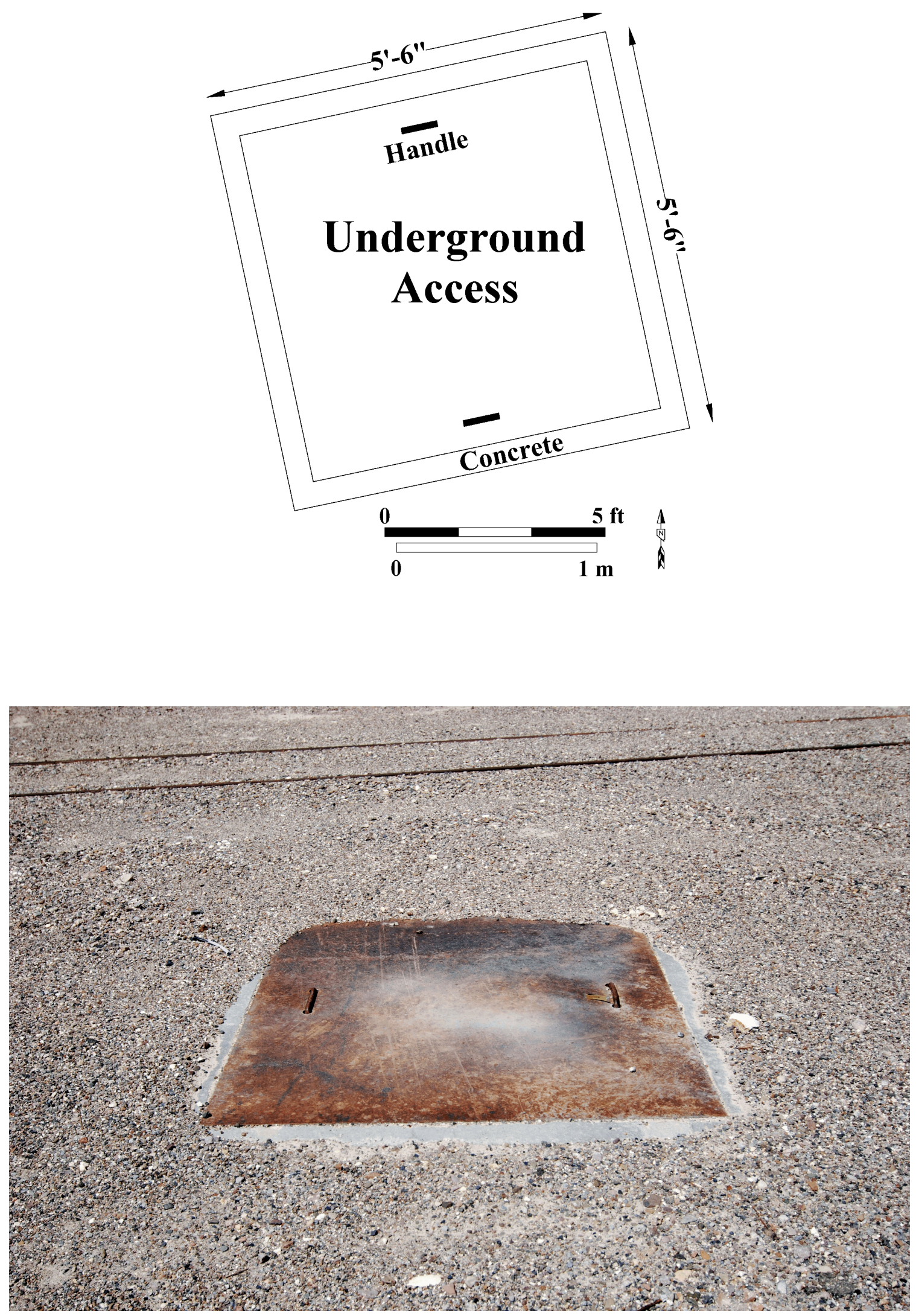

Figure 75. Plan map and photograph of Feature 16, U12t Tunnel, view northeast (2007). 

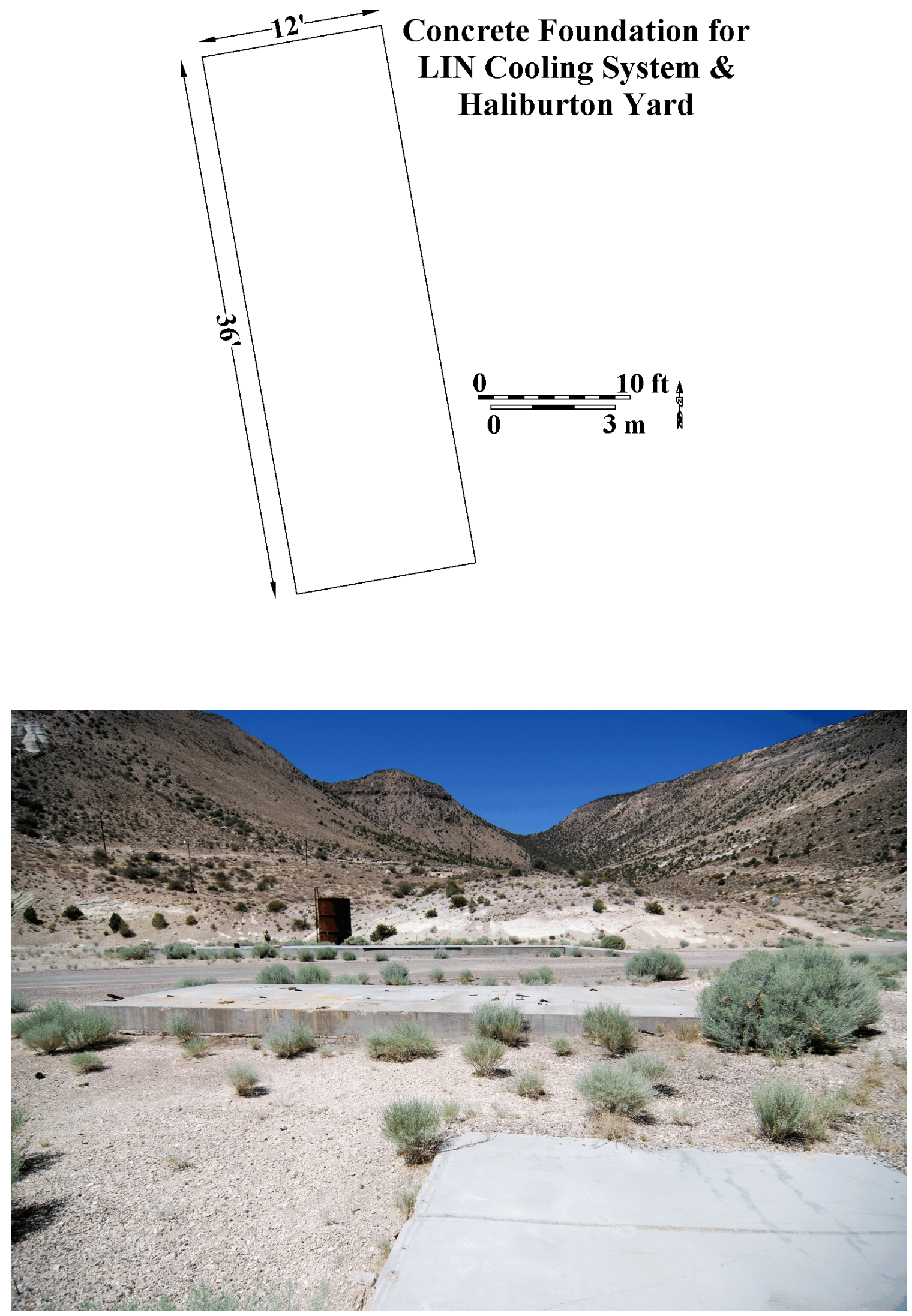

Figure 76. Plan map and photograph of Feature 17, U12t Tunnel, view southwest (2007). 

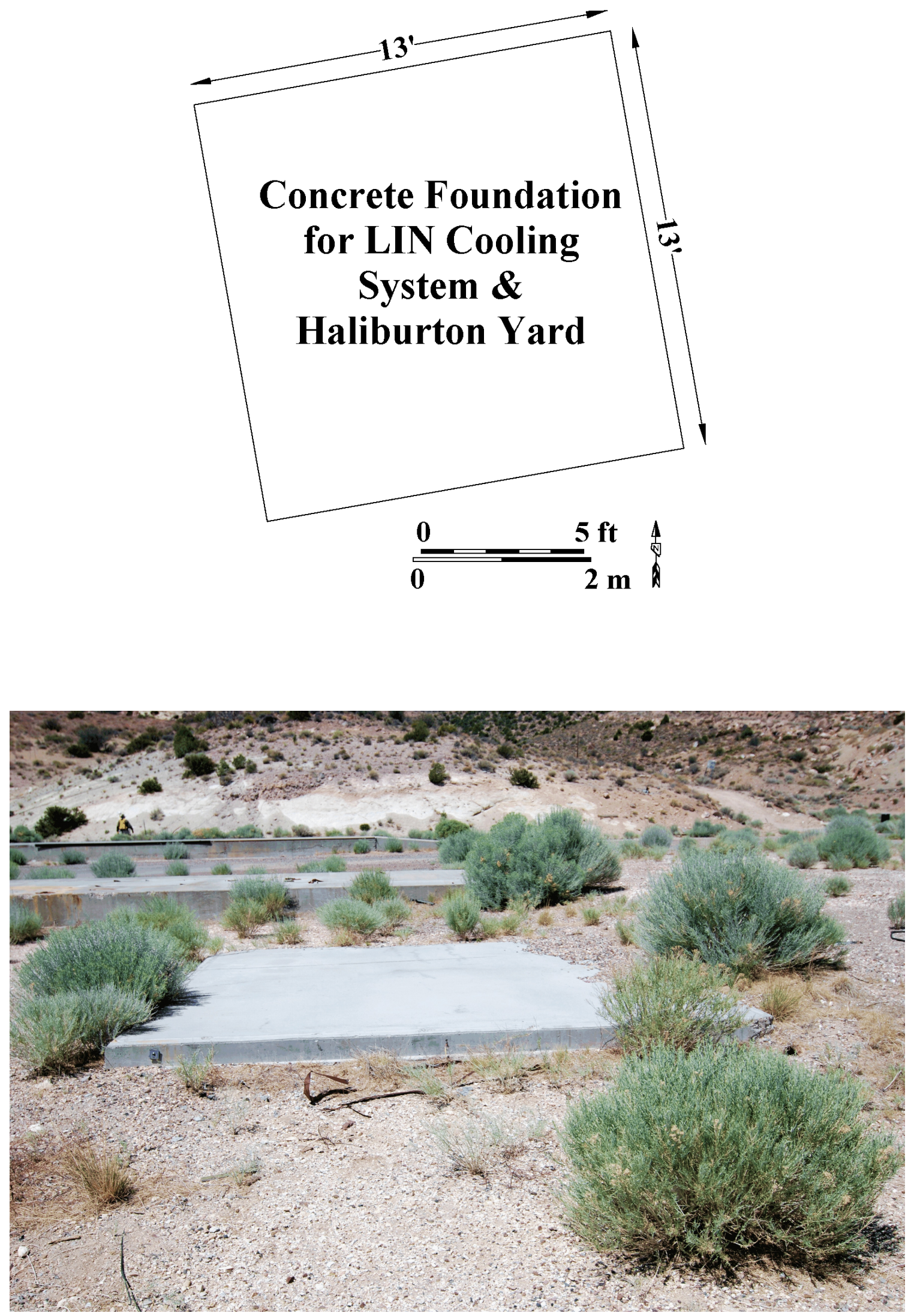

Figure 77. Plan map and photograph of Feature 18, U12t Tunnel, view west (2007). 

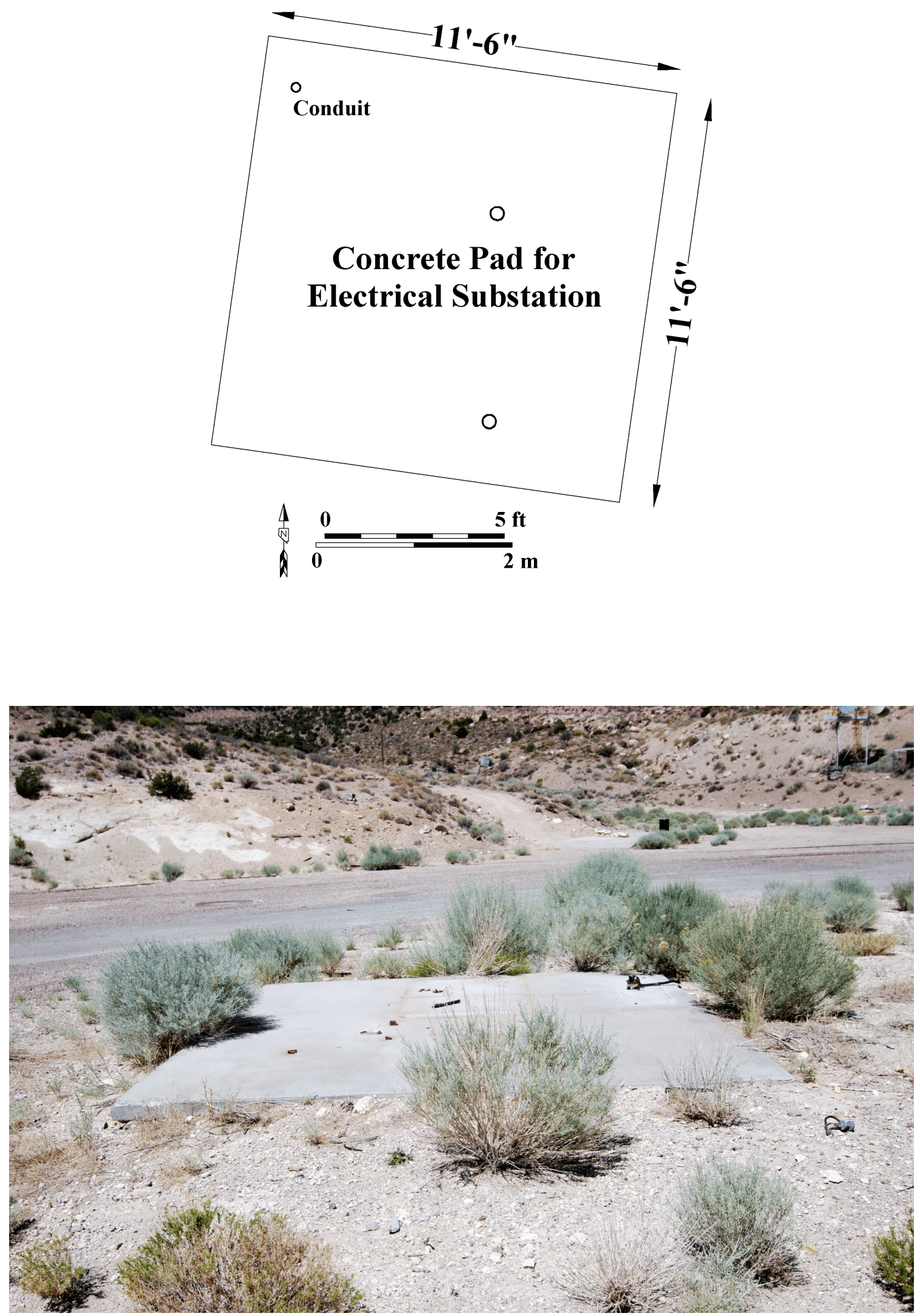

Figure 78. Plan map and photograph of Feature 19, U12t Tunnel, view northwest (2007). 
5 inches $(12.7 \mathrm{~cm})$ in diameter. Artifacts near the feature are insulated cable, metal T posts, conduit, and plywood.

\section{Feature 20}

Feature 20 is the concrete foundation for the Craft Building (Building 12-887) (Figure 79). The building housed a mechanics shop (Wayne Griffin, Larry Ashbaugh, and Byron Ristvet 2007, personal communications). The feature consists of a concrete foundation with two concrete ramps. The foundation is $60 \mathrm{ft}$ east-west by $20 \mathrm{ft}$ north-south. Impressions in the concrete indicate the attachment of metal beams to the pad surface. Also, 11/16 inch $(1.7 \mathrm{~cm})$ bolts for attachment of the beams to the concrete have been cut flush with the surface. The southeast corner of the foundation is covered with soil sloughing down slope from an access road on the ridge near the pad. At the east and west ends of the pad, $2 \mathrm{ft}$ from the north edge, are two $6 \mathrm{ft}$ east-west by $12 \mathrm{ft}$ north-south concrete ramps. Artifacts near the feature are milled lumber, insulated cable, and a 55-gallon metal drum.

\section{Feature 21}

Feature 21 is an electrical substation (12-8-47-1) (Figure 80). The substation consists of a concrete pad, chain-link fence, transformers, electrical switches, panel, and conduit. The pad is $21 \mathrm{ft}$ east-west by $20 \mathrm{ft}$ north-south. The $6 \mathrm{ft}$ east-west by $20 \mathrm{ft}$ north-south chain-link fence secures the transformers on the northwest side of the pad. The fence is $8 \mathrm{ft}$ in height with 3 strands of barbed wire above the chain-link. A 36-inch wide locked gate is on the west end of the fence. Inside of the fenced area are three electrical transformers bolted to an $8 \mathrm{ft}$ north-south by $5 \mathrm{ft}$ east-west metal plate. The plate is bolted to the surface of the pad. Also along the north edge are two electrical auto switch closures that are $36 \times 32$ inches $(91.4 \times 81.3 \mathrm{~cm})$. Associated with the switches is a 12-inch high voltage panel box. Along the north side of the concrete pad, $6 \mathrm{ft}$ from the northeast corner, is a $8 \mathrm{ft}$ long (north-south) by $6 \mathrm{ft} 6$ inch $(2 \mathrm{~m}$ ) tall metal frame (panel backboard). Attached to the frame is a $20 \times 6 \times 12$ inch electrical switch box and a 42 x 24 x 6 inch electrical panel box (both are labeled $480 \mathrm{~V}$ ). Extending east from the panel box, through the chain-link fence, and along the ground surface, is a $31 / 2$ inch $(3.9 \mathrm{~cm})$ diameter conduit that terminates at Feature 50. Extending through the ground surface along the east edge of the pad are 13 metal conduits. Four of the conduits are $21 / 2$ inches $(6.4 \mathrm{~cm})$ in diameter, five are $31 / 2$ inches $(3.9 \mathrm{~cm})$, two are $13 / 4$ inches $(4.4 \mathrm{~cm})$, and two are 1 inch $(2.5 \mathrm{~cm})$ in diameter. Insulated cables of various sizes have been cut within the conduit. Rust impressions on the concrete pad indicate that two more objects were bolted to the pad but have been removed. Artifacts near the feature are conduit, bolts, nuts, and insulated wire.

Feature 22

Feature 22 is a concrete foundation for the Portal Recording Facility, Building 12-890 (Figure 81). The feature consists of a main concrete foundation and seven secondary concrete pads. The foundation is $60 \mathrm{ft}$ east-west by $21 \mathrm{ft}$ north south and has an $8 \mathrm{ft} 8$ inches $(2.67 \mathrm{~m})$ east-west by $6 \mathrm{ft}$ north-south extension centered along the south edge (both constructed in one test). The extension 

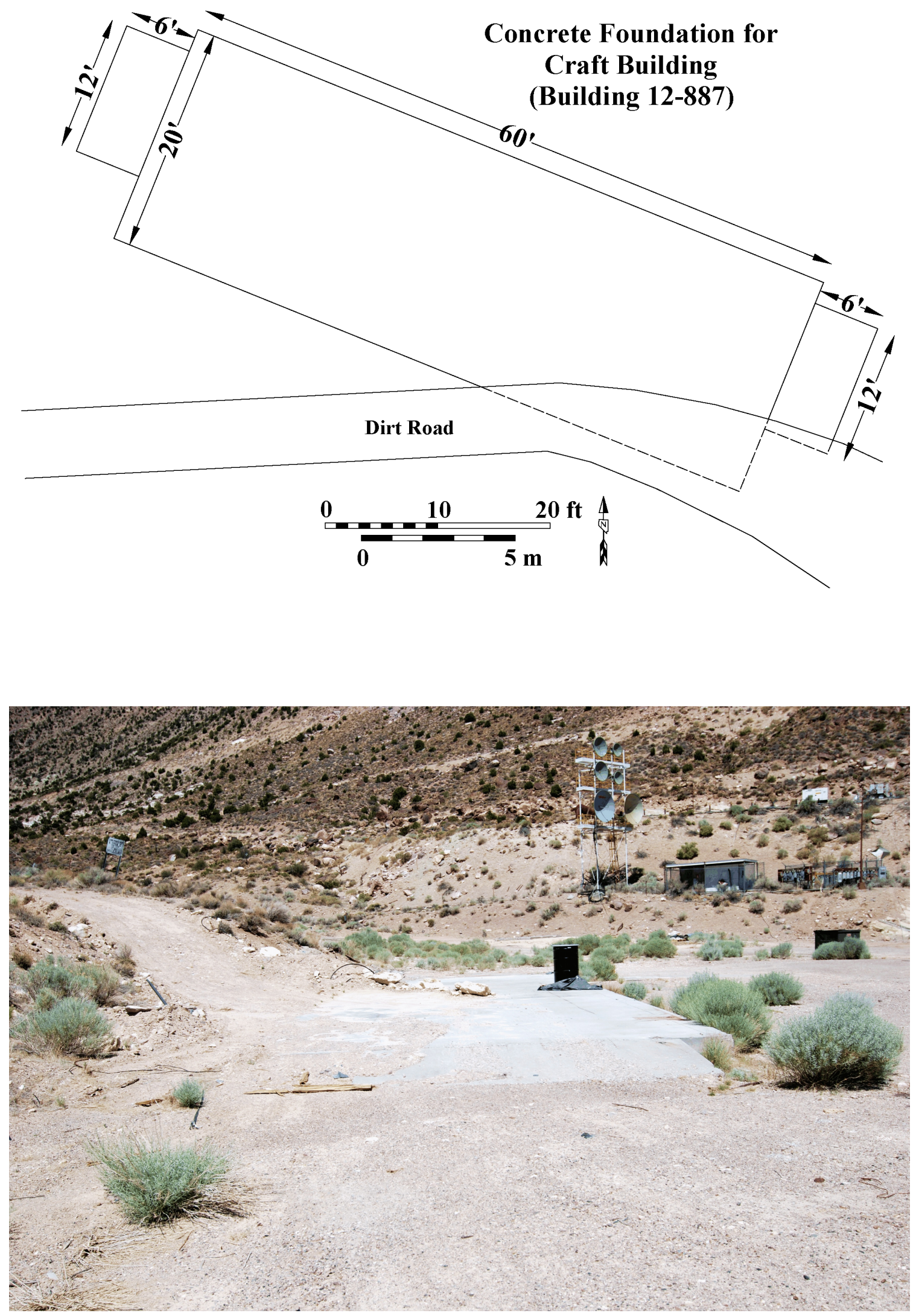

Figure 79. Plan map and photograph of Feature 20, U12t Tunnel, view northwest (2007). 

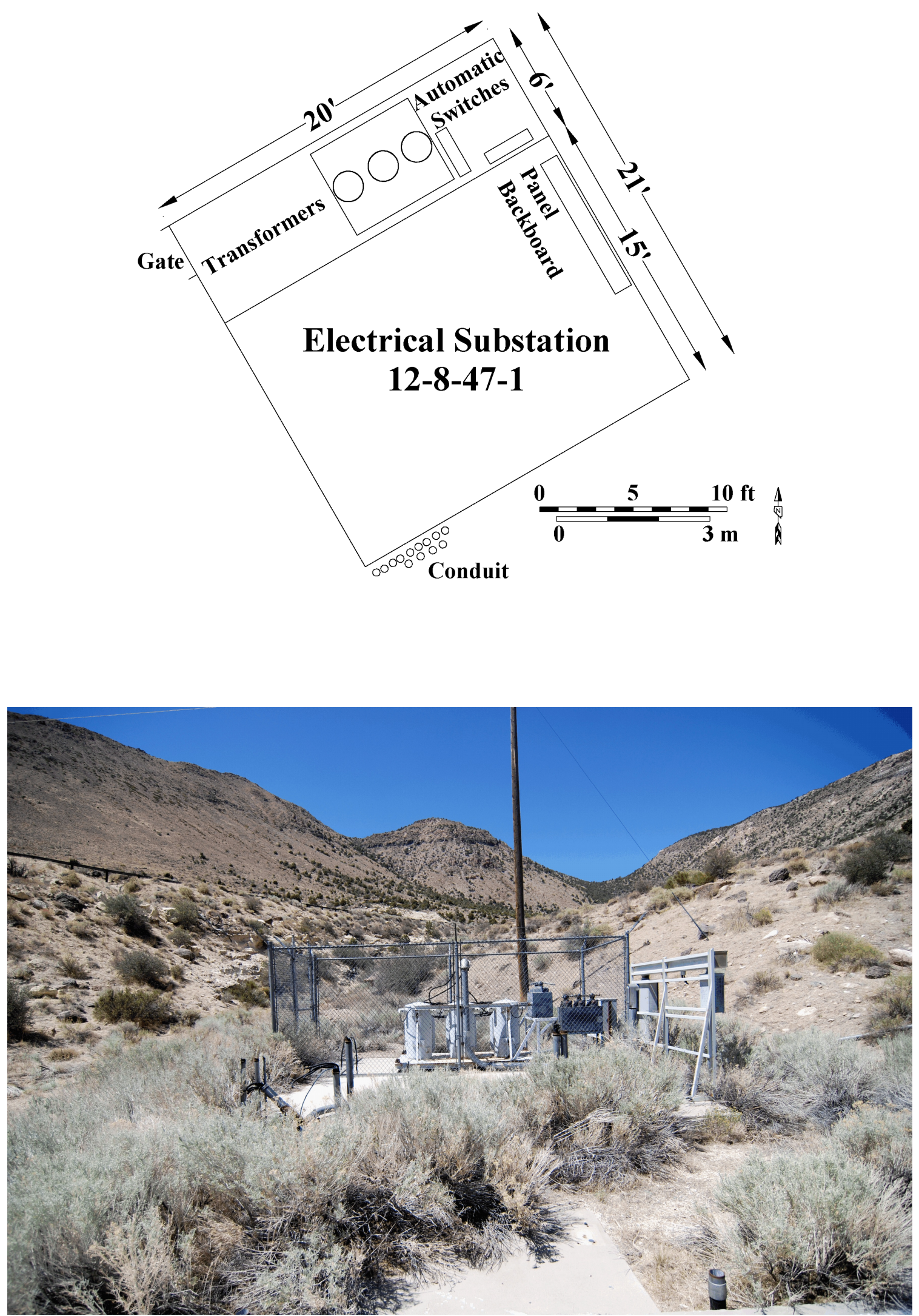

Figure 80. Plan map and photograph of Feature 21, U12t Tunnel, view northwest (2007). 

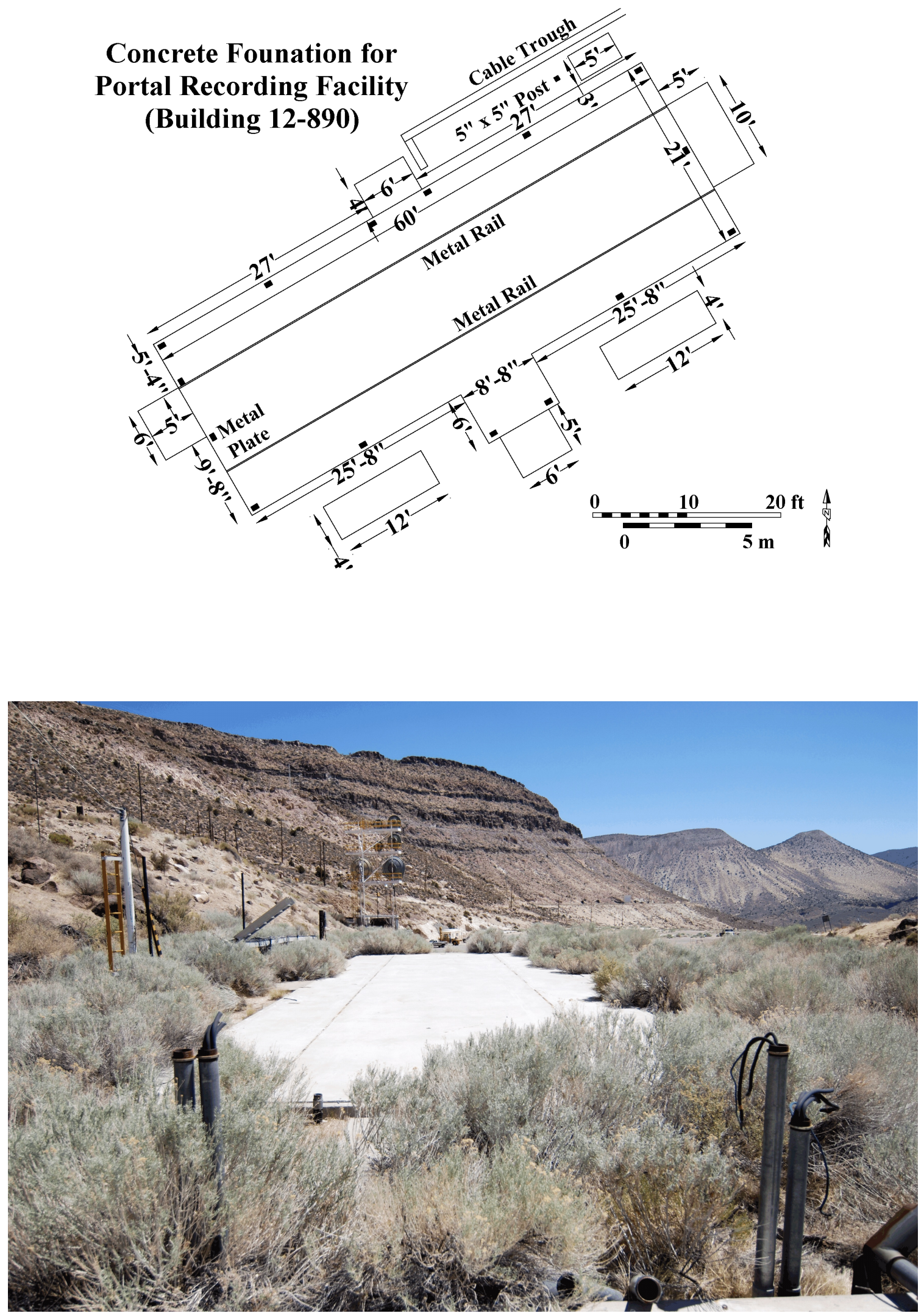

Figure 81. Plan map and photograph of Feature 22, U12t Tunnel, view northeast (2007). 
appears to the be the entrance into the building. Two metal plates are embedded in the surface of the extension that may have supported a covered entry. Around the top perimeter edge of the foundation are fifteen $9 \times 6$ inch $(22.9 \times 15.2 \mathrm{~cm})$ metal plates embedded in the surface of the concrete that supported posts of the original building. The plates were attached with $5 / 8$ inch $(1.6 \mathrm{~cm})$ bolts that have been cut flush with the pad surface. Embedded in the foundation are two 1 1/2 inch metal rails that extend east-west across the length of the pad. The rails are $5 \mathrm{ft} 4$ inches from the north and south edges of the pad.

The remaining concrete pads were constructed separately from the foundation. Along the south edge of the foundation extension is a $6 \mathrm{ft}$ east-west by $5 \mathrm{ft}$ north south concrete pad. Two $12 \mathrm{ft}$ east-west by $4 \mathrm{ft}$ north-south concrete pads flank the extension. They are $7 \mathrm{ft}$ from the east and west edges and $3 \mathrm{ft}$ south of the foundation. Along the west edge of the foundation, $5 \mathrm{ft} 4$ inches $(1.6 \mathrm{~m})$ from the northwest corner, is a $6 \mathrm{ft}$ north-south by $5 \mathrm{ft}$ east-west concrete pad. Along the north edge and centered on the foundation is a $6 \mathrm{ft}$ east-west by $4 \mathrm{ft}$ north-south concrete pad. A $5 \mathrm{ft}$ east-west by $3 \mathrm{ft}$ north-south concrete pad is 18 inches $(46 \mathrm{~cm})$ north of the foundation and near the northeast corner. Two feet west of the foundation is a $5 \times 5$ inch metal post. Along the east edge of the foundation and $5 \mathrm{ft} 4$ inches from the northeast corner is a $10 \mathrm{ft}$ north-south by $5 \mathrm{ft}$ east-west concrete pad. Also, a cable trough (Feature 23) is near the concrete pad along the north edge of the foundation. Artifacts near the feature are wire and milled lumber.

\section{Feature 23}

Feature 23 is a $115 \mathrm{ft}(35 \mathrm{~m})$ metal cable trough (Figure 82). The trough is constructed of two $7 \mathrm{inch}$ $(17.8 \mathrm{~cm})$ tall aluminum I beams that extend the length of the feature. The bottoms of the I beams are connected by $1 \times 1$ inch braces (horizontal to the bottom of the I beams) 10 inches in length (forming a ladder effect). The feature is supported from the surface by 1 x 1 inch $(2.5 \times 2.5 \mathrm{~cm})$ square metal legs 42 inches in length and spaced $12 \mathrm{ft}$ apart. Insulated cables and wires are laying within the trough on the diagonal braces. The west end of the trough is near the north edge of Feature 22 (Portal Recording Facility). The east end of the trough ends at four 5 inch diameter conduits that protrude from the ground surface. A metal $54 \times 36$ inch $(137.2 \times 91.4 \mathrm{~cm})$ barricade prevents access to the end of the trough and conduit.

\section{Feature 24}

Feature 24 is an anemometer (Figure 83) for measuring wind speed and/or force. The hemispherical cup anemometer is on top of a $10 \mathrm{ft}$ tall $11 / 4 \mathrm{inch}(3.2 \mathrm{~cm})$ pipe tower (single pole). Two of the three cups attached to the three horizontal arms of the anemometer are on the surface near the base of the tower. Two guy wires (communications wire) are attached to the pipe and a third is missing. Artifacts near the feature are a roll of $4 \times 4$ inch wire fencing, a 6-ft wooden step ladder, and insulated cable. 

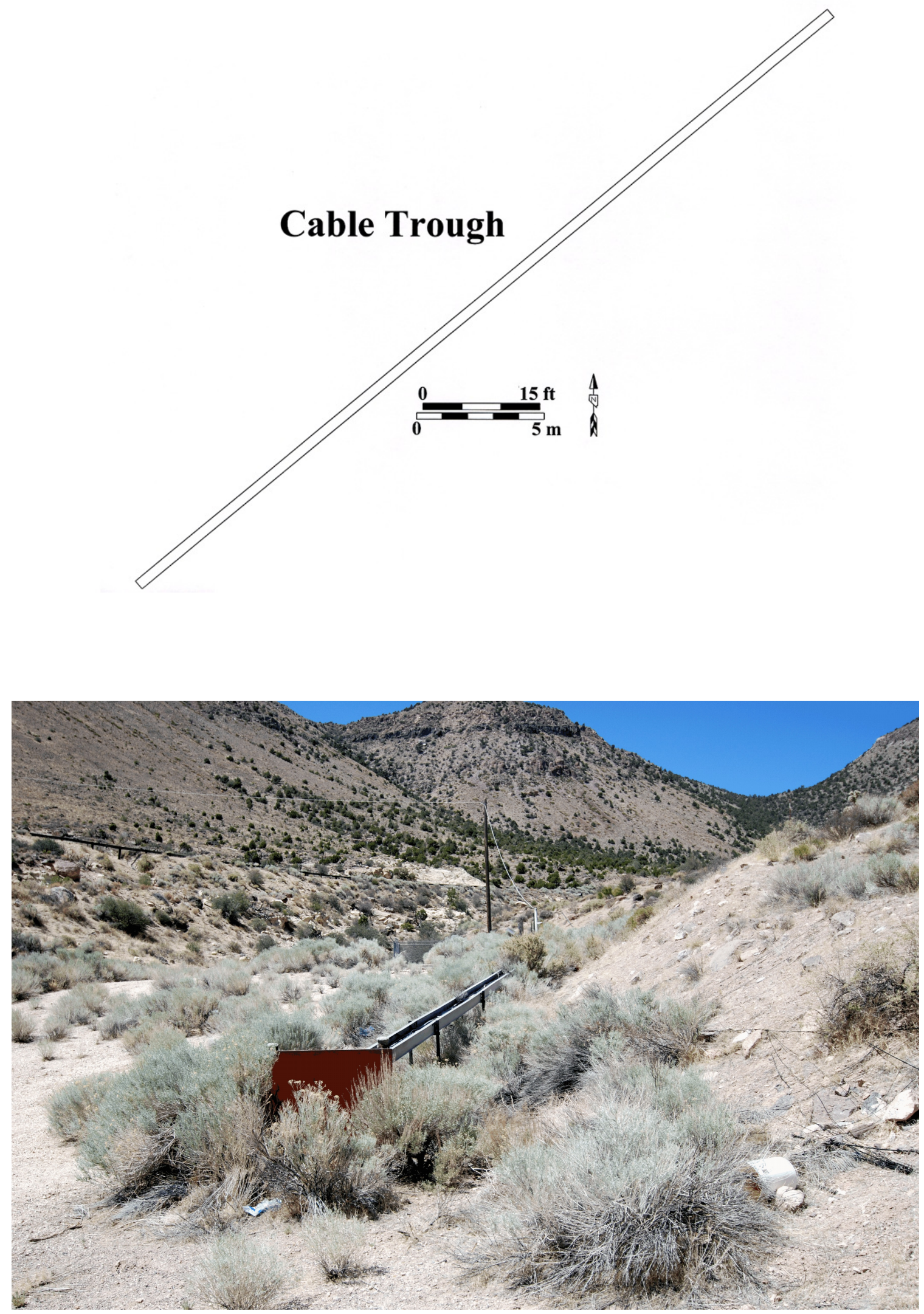

Figure 82. Plan map and photograph of Feature 23, U12t Tunnel, view southwest (2007). 


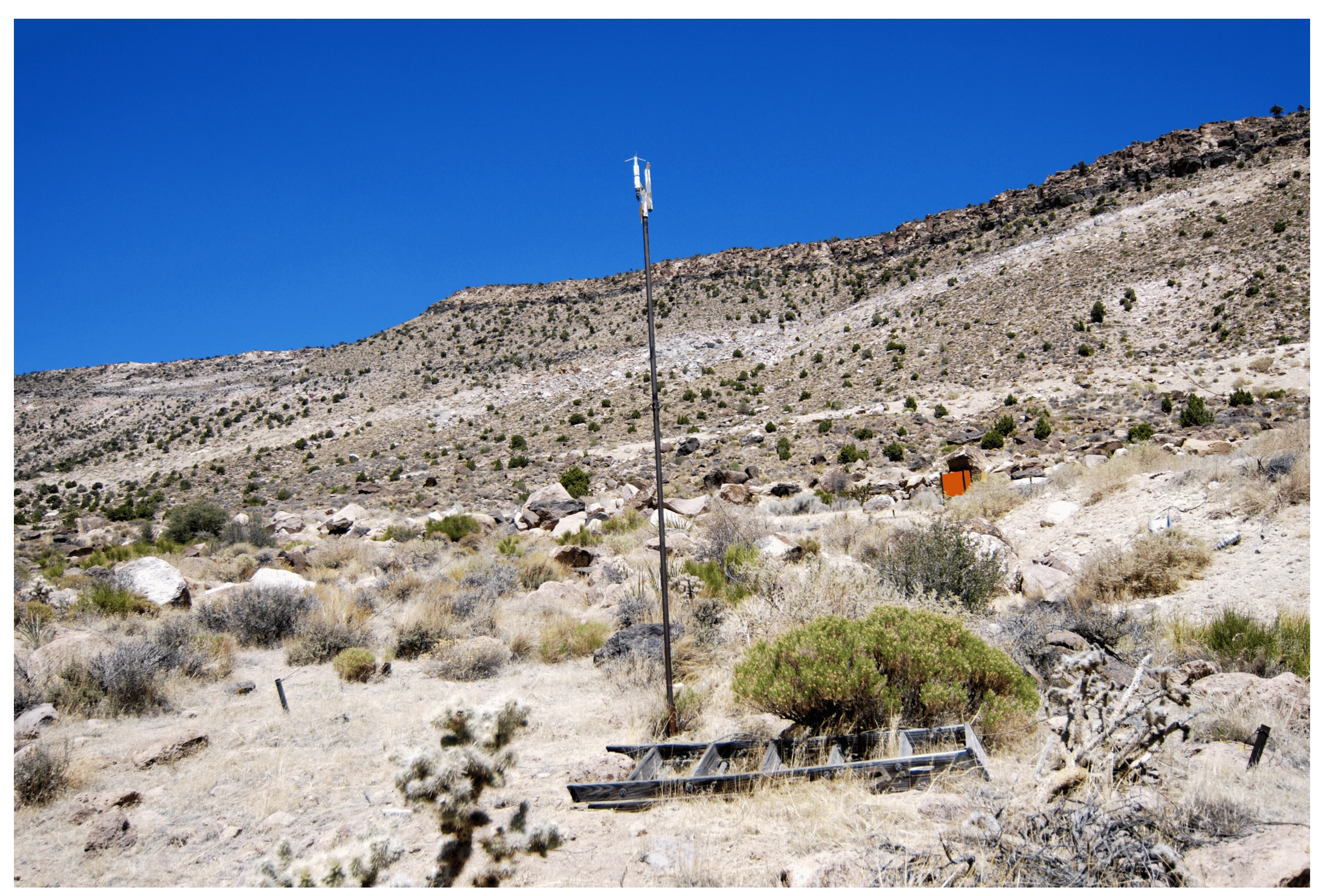

Figure 83. Photograph of Feature 24, anemometer at U12t Tunnel, view northwest (2007). 
Feature 25 is a concrete foundation for the Reentry and Monitor Control Building (Building 12-894) (Figure 84 ). The feature consists of a concrete foundation and smaller concrete pad. The foundation is $20 \mathrm{ft} 9$ inches $(6.3 \mathrm{~m})$ east-west by $10 \mathrm{ft} 9$ inches $(3.3 \mathrm{~m})$ north-south and is 8 inches thick. Around the top perimeter edge of the foundation is a $41 / 2 \mathrm{inch}$ wide by $1 / 4$ inch deep recess for the bottom plate of the building. At each corner of the foundation are $12 \times 12$ inch metal plates attached to the concrete with 1 inch bolts. Additional bolts that once protruded through the concrete have been cut flush with the surface of the foundation. A 1 1/2 inch metal strap is embedded in the concrete and extends east-west across the foundation. The strap begins and ends 48 inches from the east and west edges. Along the south edge of the foundation, 40 inches from the northwest corner, is a $5 \mathrm{x} 5 \mathrm{ft}$ concrete pad (possible stoop) that was poured separately from the foundation. Artifacts near the feature are nuts, bolts, and 3/4 inch plastic or plexiglass fragments.

\section{Feature 26}

Feature 26 is a concrete foundation for the Health Physics Trailer (Figure 85). The foundation is 25 $\mathrm{ft}$ east-west by $9 \mathrm{ft}$ north-south and is 6 inches thick. Along the south side at the southwest corner is a $5 \times 5 \mathrm{ft}$ concrete pad. Flush with the surface of the pad around the to perimeter edge are 11/16 inch lead anchors for the attachment of molly bolts. Artifacts near the pad are metal plates, milled lumber, insulated cable, cable jacks, and metal fragments.

\section{Feature 27}

Feature 27 is a microwave tower (Figure 86). The tower faces east, is triangular in shape (each side $15 \mathrm{ft}$ ), is approximately $40 \mathrm{ft}(12.2 \mathrm{~m})$ tall, and supports six parabolic disks (two $8 \mathrm{ft}$, two $4 \mathrm{ft}$, and two $3 \mathrm{ft}$ in diameter). Each leg of the tower is 4-inch metal pipe supported by $4 \mathrm{x} 4 \mathrm{x} 4 \mathrm{ft}$ concrete blocks. The legs are attached to the blocks by a $28 \times 28$ inch $(71.1 \times 71.1 \mathrm{~cm})$ metal plate recessed into the concrete block. Each plate is secured to a block with 11/16 inch bolts. Diagonal bracing between the legs consists of two pieces of $21 / 2$ inch angle iron welded together to form a T-shaped brace. Additional bracing is from 1 inch metal rods with turnbuckles for tensioning. Three $25 \mathrm{ft}$ long by $3 \mathrm{ft}$ wide metal platforms provide access to the parabolic dishes. Each platform is accessed by metal ladders.

The lower platform is at $20 \mathrm{ft}$ above the surface and accesses two $8 \mathrm{ft}$ diameter parabolic dishes; one attached to the south and one to the north leg of the tower. The middle platform is $30 \mathrm{ft}$ above the surface and accesses two parabolic dishes (one $3 \mathrm{ft}$ and one $4 \mathrm{ft}$ ). One $4 \mathrm{ft}$ dish is attached to the south leg and one $3 \mathrm{ft}$ dish is attached to a vertical support centered on the east face of the tower. The support extends from the center of the lower platform and extends $4 \mathrm{ft}$ above the top platform. The top platform is $40 \mathrm{ft}$ above the surface and accesses the remaining two dishes (one $3 \mathrm{ft}$ and one $4 \mathrm{ft}$ ). One $4 \mathrm{ft}$ dish is attached to the south leg and one $3 \mathrm{ft}$ dish is attached to a vertical support between the legs. Artifacts near the feature are two high pressure nitrogen cylinders, angle iron, plywood, and insulated cable. 

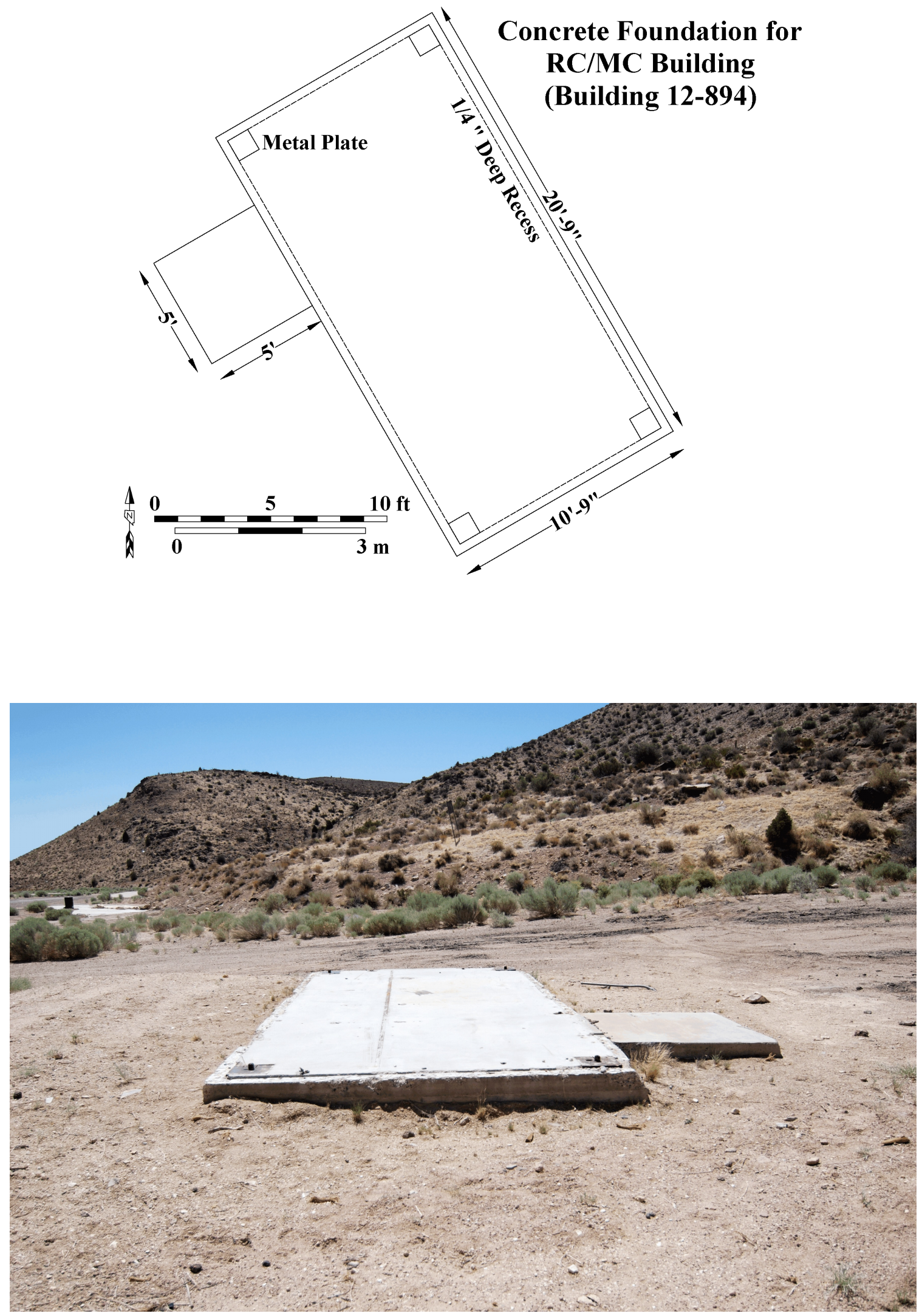

Figure 84. Plan map and photograph of Feature 25, U12t Tunnel, view southeast (2007). 

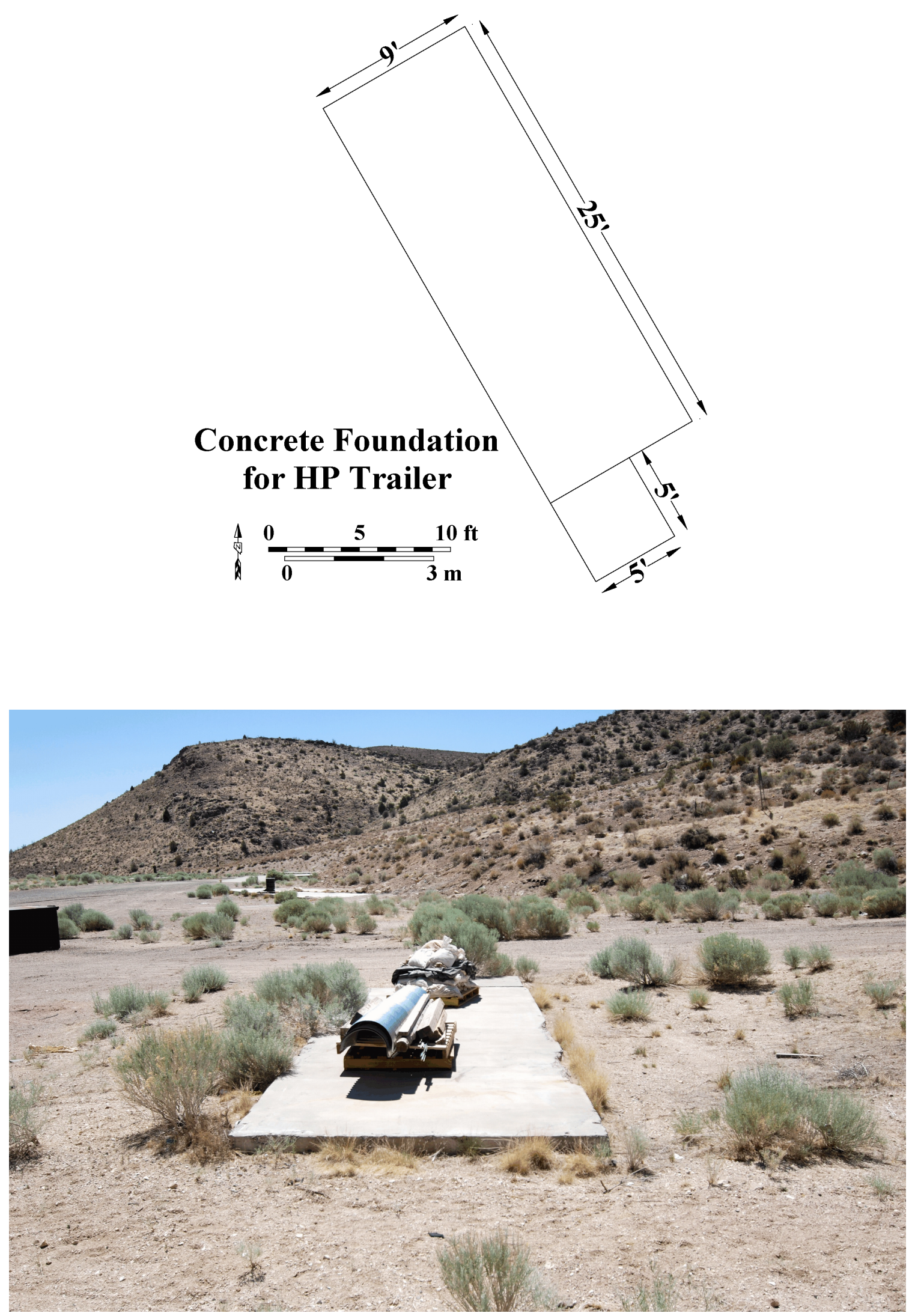

Figure 85. Plan map and photograph of Feature 26, U12t Tunnel, view southeast (2007). 

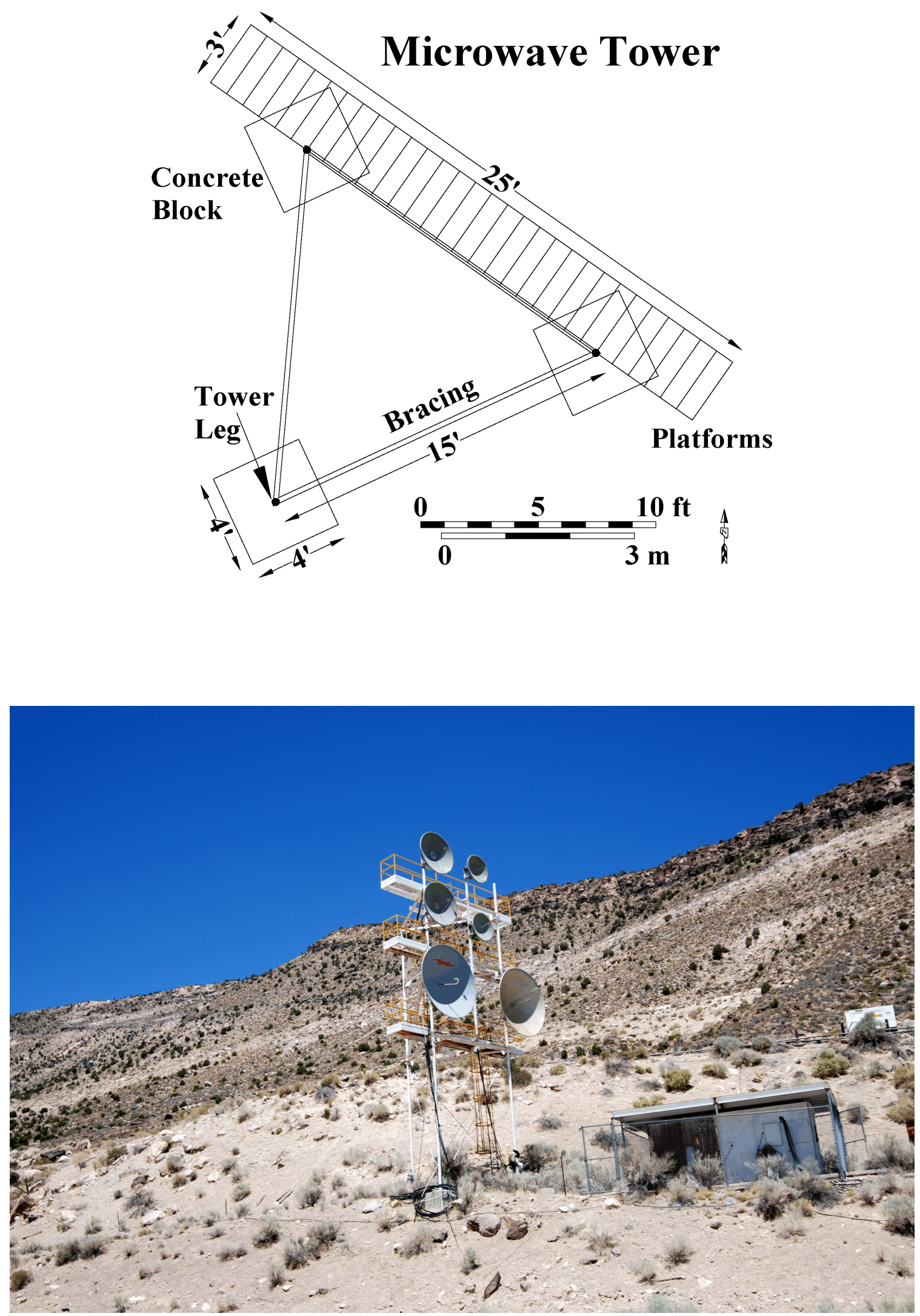

Figure 86. Plan map and photograph of Feature 27, U12t Tunnel, view northwest (2007). 
Feature 28

Feature 28 is a concrete pad that is $7 \mathrm{ft}$ east-west by 44 inches $(1.1 \mathrm{~m})$ north-south and is 12 inches thick (Figure 87). On each corner, 7 inches from the east and west edges and 14 inches $(35.6 \mathrm{~cm})$ from the north and south edges are four $3 / 8 \mathrm{inch}(1 \mathrm{~cm})$ bolts protruding through the surface of the concrete. No use for the feature has been determined at this time. Artifacts near the feature are wood fragments and a coffee can.

Feature 29

Feature 29 is a power control station listed on the 1984 engineering drawing as a concrete slab. (Figure 88). The feature consists of a chain-link fence supporting a metal roof, a concrete foundation, and a plywood brockhouse. The fence is $23 \mathrm{ft}(7 \mathrm{~m})$ east-west by $17 \mathrm{ft} 6$ inches $(5.3 \mathrm{~m})$ north-south and $9 \mathrm{ft} 6$ inches $(2.9 \mathrm{~m})$ in height. Six metal posts anchor the fence and support the roof. The posts are set in concrete blocks $44 \times 44 \times 16$ inches $(111.8 \times 111.8 \times 4 \mathrm{~cm})$. The roof is framed with 6 inch I beam and covered with corrugated metal. The concrete foundation is $29 \mathrm{ft}$ east-west by $9 \mathrm{ft}$ northsouth and extends east $4 \mathrm{ft}$ outside of the chain-link fence. The foundation sets back $1 \mathrm{ft}$ from the west and $3 \mathrm{ft}$ from the south edge of the fence. The plywood brockhouse is $18 \mathrm{ft}$ east-west by $8 \mathrm{ft}$ north-south and is $8 \mathrm{ft} 2$ inches $(2.5 \mathrm{~m})$ in height. Entry is through a 32-inch wide door opening is on the southwest corner of the building, however, the door is missing. There is an $18 \times 21$ inch (45.7 $\mathrm{x} 53.3 \mathrm{~cm}$ ) opening in the east wall (possible window now missing) and on the exterior of the east wall is stenciled DOD BH 54. On the exterior of the north and south walls are small electrical panels. The interior of the brockhouse contains electrical panels and furniture. In the northwest corner along the north wall is a $7 \mathrm{ft}$ long by $6 \mathrm{ft}$ high by $2 \mathrm{ft}$ wide electrical switch panel that once controlled the ventilation system in the tunnel (switches labeled on panel). Along the south wall are six small switch panels that controlled reentry equipment in the tunnel (switches labeled reentry). Along the east wall are two $1 \times 12$ inch wood shelves the width of the building. In the northeast corner is a 40 inch long by 25 inch $(63.5 \mathrm{~cm})$ wide drafting table that is 48 inches tall along the north (back) edge (slopes to south). A telephone is on the north wall above the drafting table. Lighting was supplied by one $5 \mathrm{ft}$ and one 8 - $\mathrm{ft}$ long florescent fixtures. Newspapers in the building are dated 1986. Other artifacts are a hard hat, chairs, and insulated wire.

\section{Feature 30}

Feature 30 is Portal Substation 1 (Figure 89). The substation consists of a chain-link fence surrounding a concrete pad with electrical transformers and switches and two electrical panel backboards outside the fenced area. The fenced area is $17 \mathrm{ft}$ east-west by $21 \mathrm{ft}$ north-south and is 8 $\mathrm{ft}$ in height with 3 strands of barbed wire on top of the chain-link. Entry is through a locked 48 inch wide gate is on the northeast corner. No attempt was made to enter the fenced area. The concrete pad is approximately $9 \mathrm{ft}$ east-west by $14 \mathrm{ft}(4.3 \mathrm{~m})$ north-south. Equipment on the pad consists of six electrical switches (three 24 inch diameter by 48 inch tall, one 18 inch diameter by 36 inch tall, and two 36 × 36 × 12 inch). The switches area labeled G\&W Electrical Specialty Co., 3500 W. $127^{\text {st }}$, 

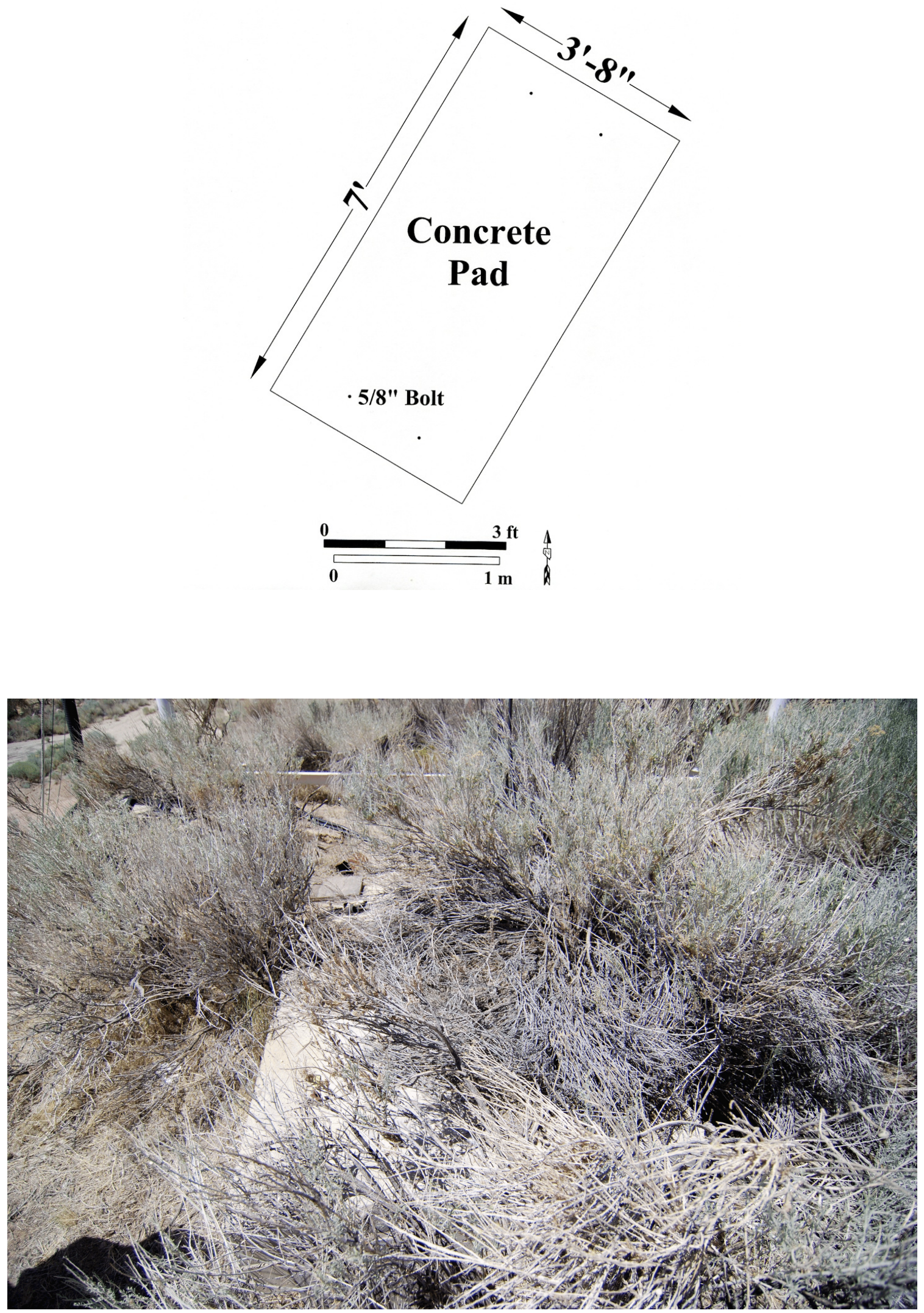

Figure 87. Plan map and photograph of Feature 28, U12t Tunnel, view northwest (2007). 

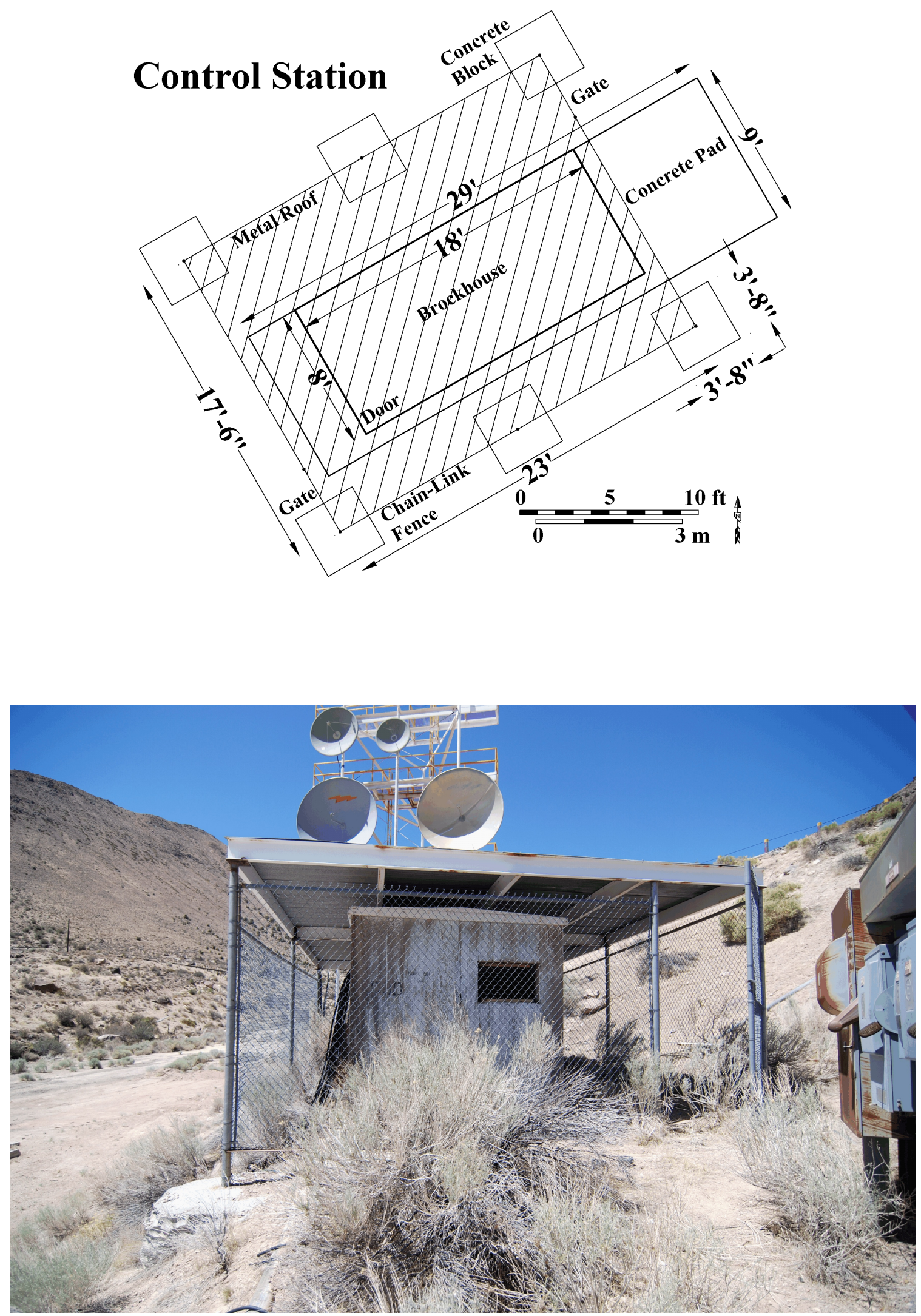

Figure 88. Plan map and photograph of Feature 29, U12t Tunnel, view southwest (2007). 

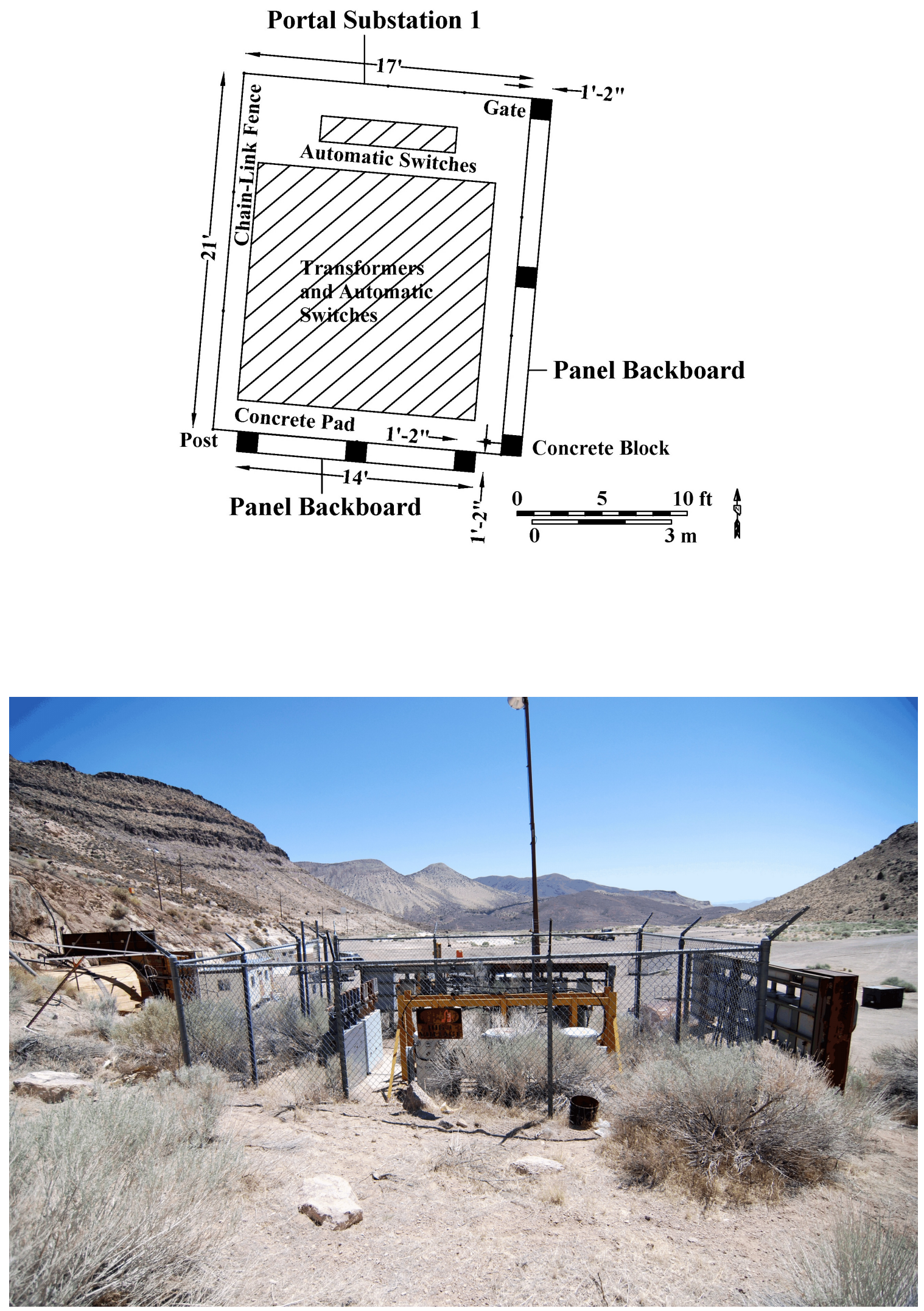

Figure 89. Plan map and Photograph of Feature 30, U12t Tunnel, view southeast (2007). 
Blue Island, Illinois. They are 5.25 KV, $200 \mathrm{amp}$, type FC-42 and the west switch is labeled 12-8-462 and the east switch is labeled 12-8-46-1.

One electrical panel backboard is south and outside of the fenced area. The backboard is a metal frame on which electrical panels and switches are mounted. The frame is $14 \mathrm{ft}$ east-west by 74 inches $(1.9 \mathrm{~m})$ in height and is constructed of $11 / 2$ inch channel iron. It is supported by three legs embedded in concrete pads, 14 inches in diameter. Eleven panel or switch boxes are secured to the frame and are labeled 240 volts. The boxes range in size from $9 \times 4 \times 2$ inches $(22.9 \times 10.2 \times 5.1 \mathrm{~cm})$ to $27 \times 13 \times 7$ inches $(68.6 \times 33.0 \times 17.8 \mathrm{~cm})$ with 4 inch diameter conduit attached to the two of largest boxes mounted on the east and west ends of the frame.

The second electrical panel backboard is east and outside of the fenced area. The backboard is a 18 $\mathrm{ft}$ long by $7 \mathrm{ft}$ tall frame constructed of $11 / 2$ inch channel iron. It is supported by three legs buried in the surface. Attached to the frame are 14 panel or switch boxes ranging in size from $1 \times 1 \times 4$ inches to $45 \times 29 \times 9$ inches $(114.3 \times 73.7 \times 22.9 \mathrm{~cm})$. All boxes are labeled 480 volts. Associated with the frame is a $5 \times 5$ inch metal light pole $16 \mathrm{ft}$ tall. Two incandescent light fixtures are supported by 18 inch braces that extend from the top of the pole. Artifacts near the feature are insulated cable and wire.

Feature 31

Feature 31 is a rough-poured concrete pad that measures $25 \mathrm{ft} 4$ inches $(7.7 \mathrm{~m})$ east-west by $33 \mathrm{ft}(10$ $\mathrm{m})$ north-south and is 10 inches $(25.4 \mathrm{~cm}$ ) thick (Figure 90$)$. It is near the east edge of the U12t Tunnel terrace and $5 \mathrm{ft}(1.5 \mathrm{~m})$ east of existing rails that extend from the portal. The purpose of the pad is not known at this time. The concrete was poured without the use of forms, was not leveled, and the surface was left unfinished except for a small area at the northeast corner. Visual inspection through multiple cracks in the surface revealed that no reinforcement was used in its construction. Also, no fasteners were found to indicate that a structure or equipment was attached to the pad. Artifacts near the pad are electrical conduit, insulated cable, milled lumber, and metal plates.

Feature 32

Feature 32 is the concrete foundation for the Walker Shack and Lamp House (Figure 91). The feature consists of a concrete foundation that is $60 \mathrm{ft}$ east-west by $21 \mathrm{ft}$ north-south. No fasteners or impressions to indicate attachment of a structure were found on the concrete. At present, the foundation supports a trailer that obscures the surface of the foundation. No artifacts were found near the feature.

Feature 33

Feature 33 is a concrete foundation for a Dry Storage Building (Figure 92). The feature consists of a concrete foundation and two smaller concrete pads. The foundation measures $60 \mathrm{ft}$ east-west by $20 \mathrm{ft}$ north-south. Along the east and west edges of the foundation, 18 inches from the south edge, 

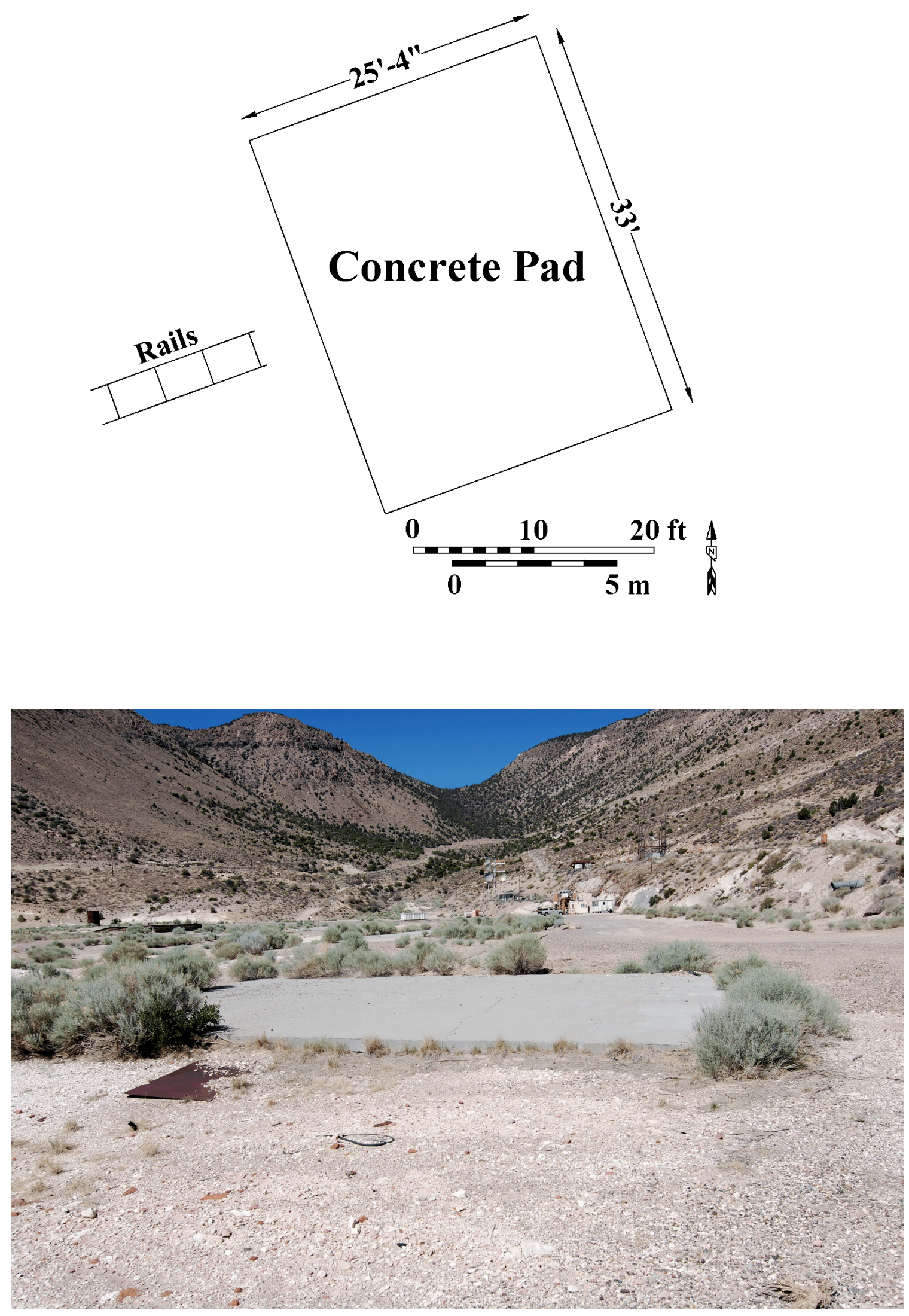

Figure 90. Plan map and photograph of Feature 31, U12t Tunnel, view southwest (2007). 

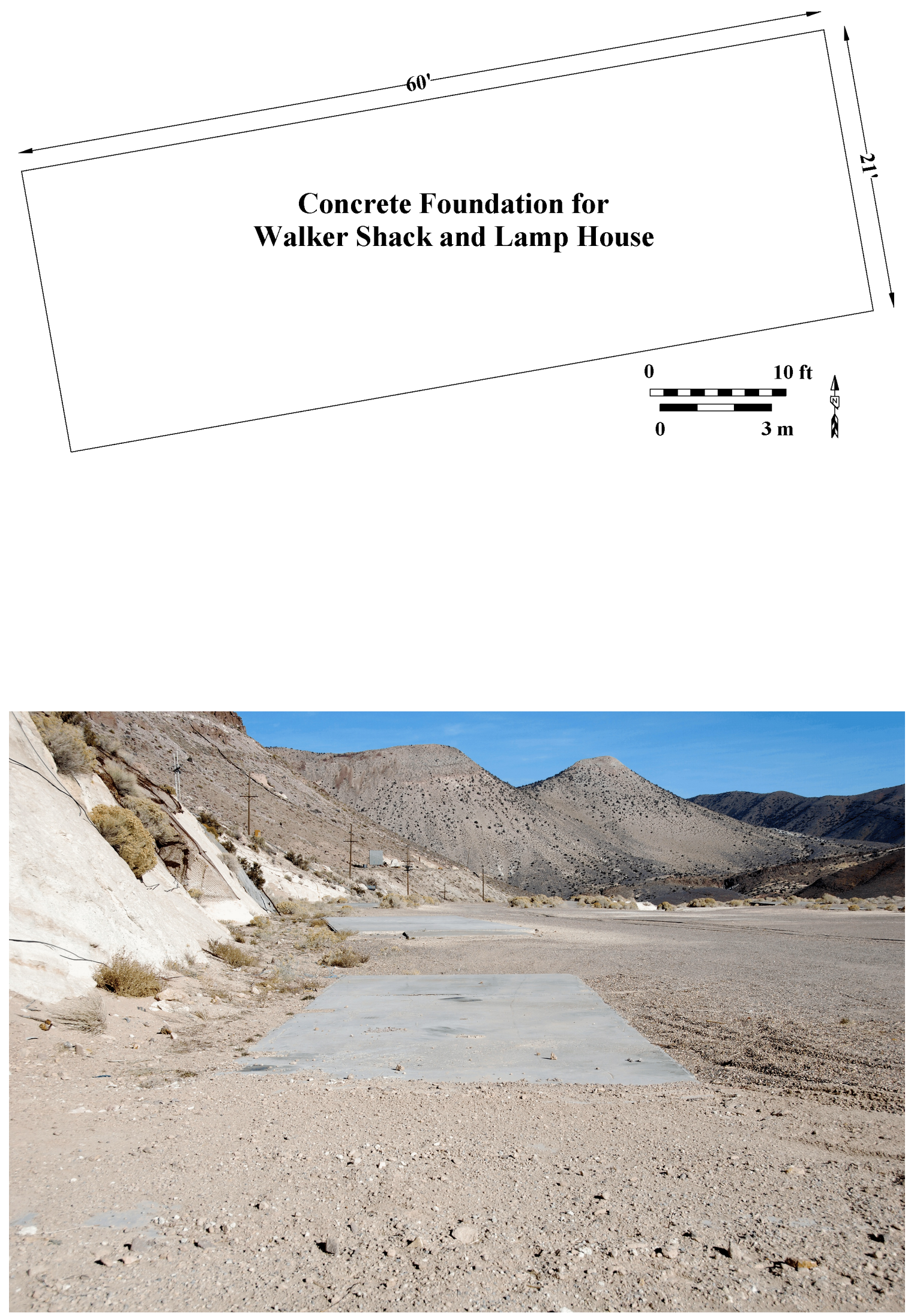

Figure 91. Plan map and photograph of Feature 32, U12t Tunnel, view northeast (2007). 

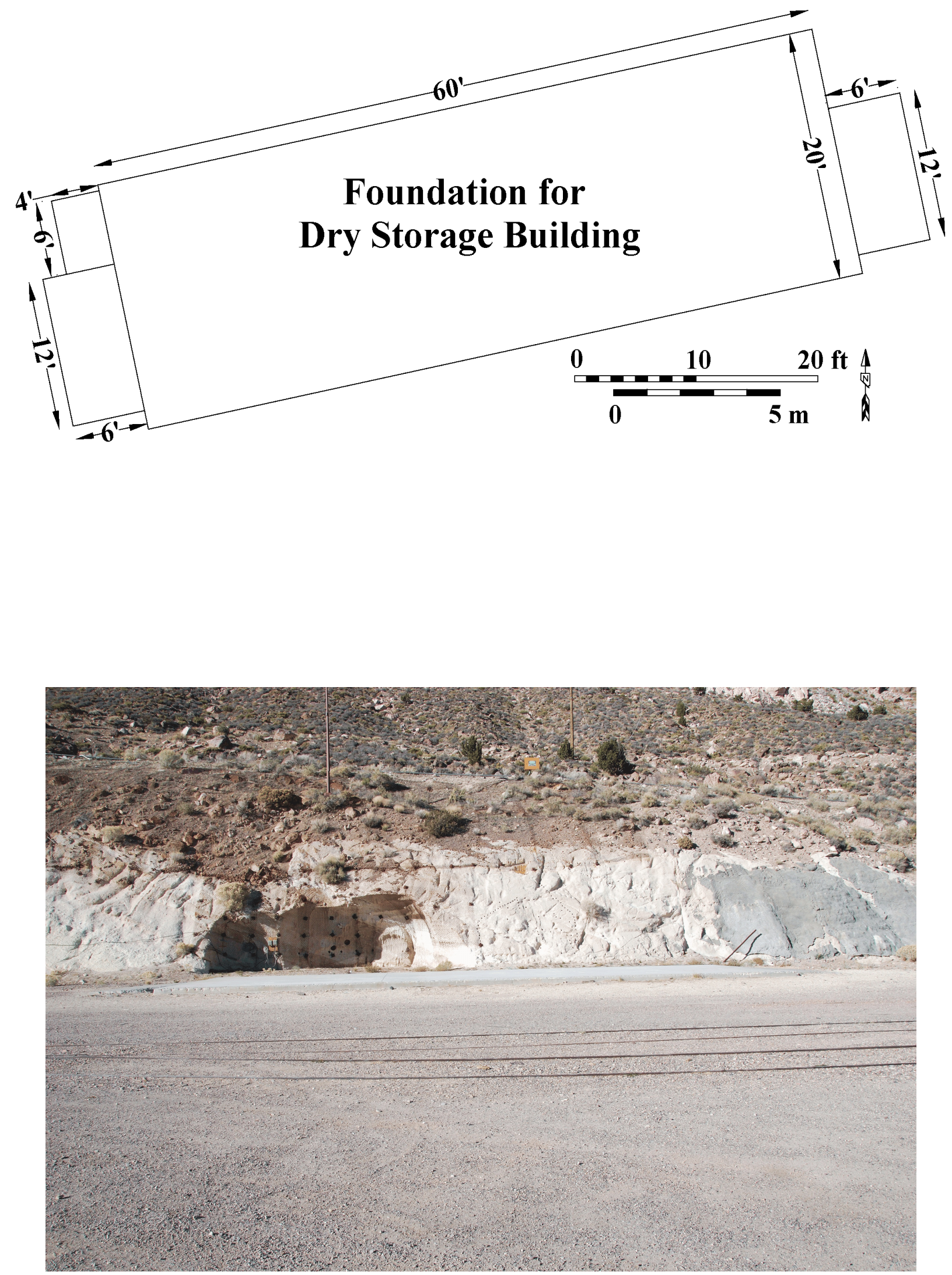

Figure 92. Plan map and photograph of Feature 33, U12t Tunnel, view northwest (2007). 
are two $6 \mathrm{ft}$ east-west by $12 \mathrm{ft}$ north south concrete pads. No fasteners or impressions to indicate attachment of a structure were found on the concrete. At present, the foundation supports a trailer that obscures the surface of the foundation. No artifacts were found near the feature.

Feature 34

Feature 34 is a concrete pad approximately $20 \mathrm{ft}$ east-west by $17 \mathrm{ft}$ north-south, however, most of the pad is obscured by sediments and sand (Figure 93). The exposed surface of the concrete has a smooth finish with no indications of attachments for a structure or equipment. No use for the pad has been determined at this time. No artifacts were found near the feature.

Feature 35

Feature 35 is the concrete foundation for the Electrical Office and Shop (Figure 94). It consists of the main concrete foundation and four smaller concrete pads. The four smaller pads were constructed separately from the foundation. The foundation measures $20 \mathrm{ft} 4$ inches north-south by $60 \mathrm{ft} 4 \mathrm{inches}$ $(18.4 \mathrm{~m})$ east-west and is 6 inches thick. The surface of the concrete has a smooth finish with bolts and metal plates embedded in the surface that attached the building to the foundation. Along the east edge $2 \mathrm{ft}$ from the southeast corner of the foundation is a $4 \mathrm{ft}$ east-west by $17 \mathrm{ft}$ north-south concrete pad. Along the east edge and aligned with the southeast corner of the previous pad is a $11 \mathrm{ft}$ eastwest by $12 \mathrm{ft}$ north-south concrete pad. Along the west edge, $2 \mathrm{ft}$ from the southwest corner of the foundation, is a $4 \mathrm{ft}$ east-west by $17 \mathrm{ft}(5.1 \mathrm{~m})$ north-south concrete pad. Along the west edge and aligned with the southwest corner of the previous pad is an $11 \mathrm{ft}$ east-west by $12 \mathrm{ft}$ north-south concrete pad. Artifacts near the feature are hoses for an acetylene cutting torch, bolts, milled lumber, nuts, and washers.

Feature 36

Feature 36 is the foundation for a transformer station (Figure 95). On the 1984 engineering drawing, the foundation is labeled a steel dock. It measures $11 \mathrm{ft}$ east-west by $9 \mathrm{ft}$ north-south and is 6 inches thick. Extending through the surface of the foundation are thirteen 2 inch, 4 inch, and 5 inch diameter conduits that contain insulated cables. One 5 inch diameter conduit extends north from the foundation to a high voltage power box (Feature 50) on the main electrical power system. Artifacts near the feature are insulted wire and milled lumber.

Feature 37

Feature 37 is the two metal rails that extend from the U12t Tunnel portal and fan out across the portal terrace (Figure 96). One set of rails extend from the portal and branch into six separate lines. Four of the lines extend to the east end of the terrace and two lines extend to the southern end of the terrace. The rails are metal and spaced 36 inches apart. Ties that secure the rails are metal and generally stabilized with soil (between the rails) except in locations where concrete was used 

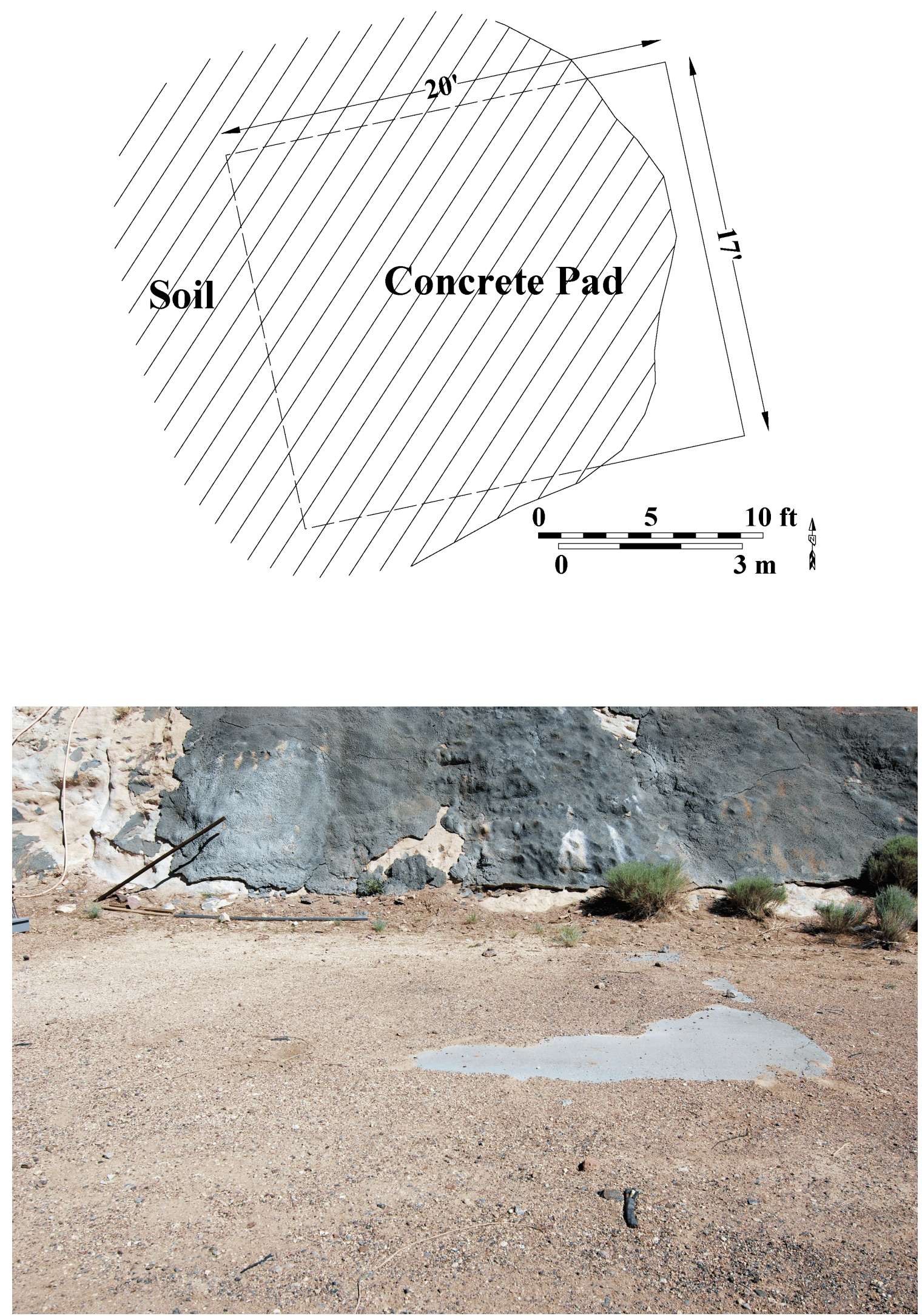

Figure 93. Plan map and photograph of Feature 34, U12t Tunnel, view northwest (2007). 

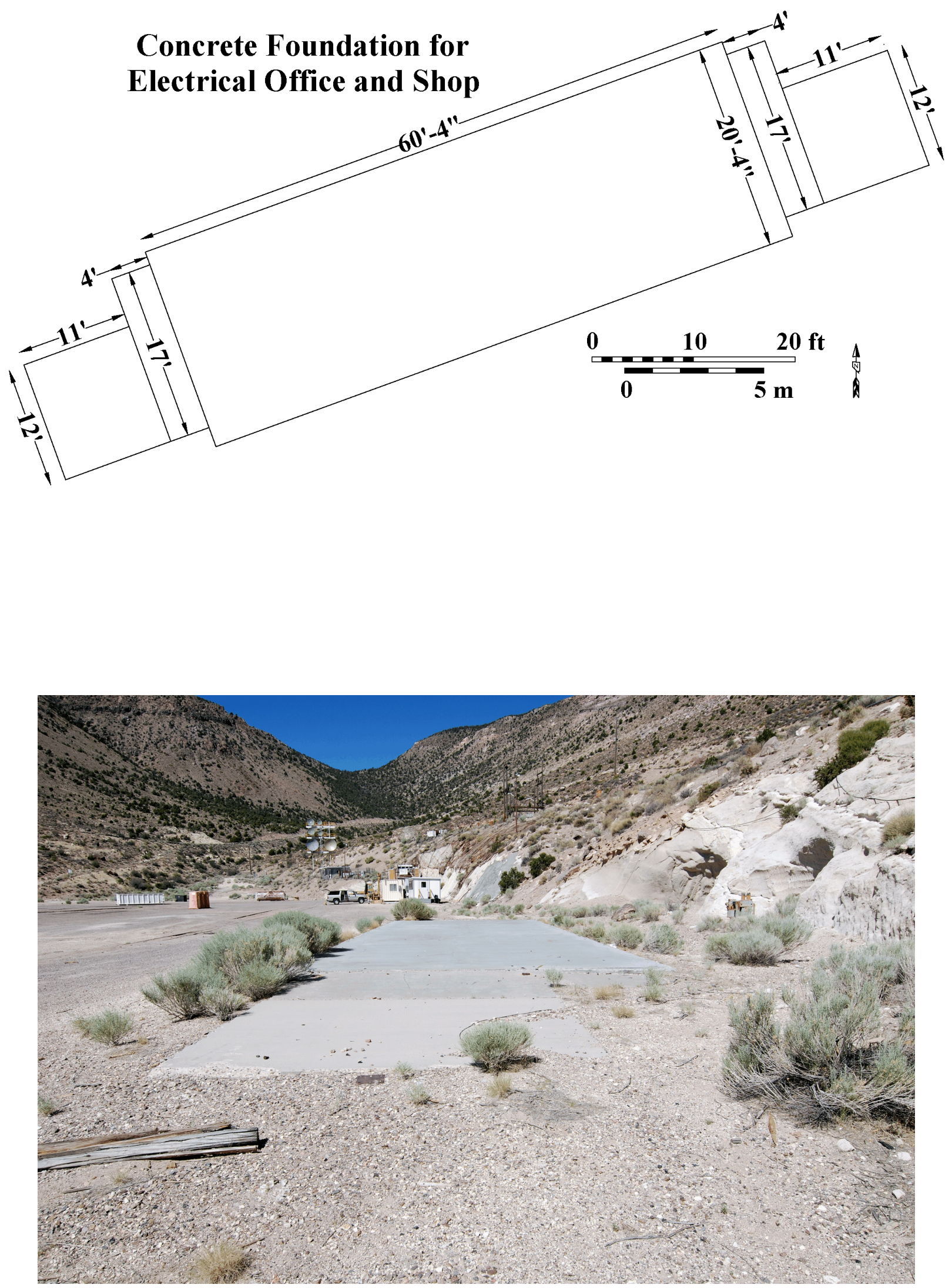

Figure 94. Plan map and photograph of Feature 35, U12t Tunnel, view southwest (2007). 


\section{Concrete Foundation for Transformer Station o}
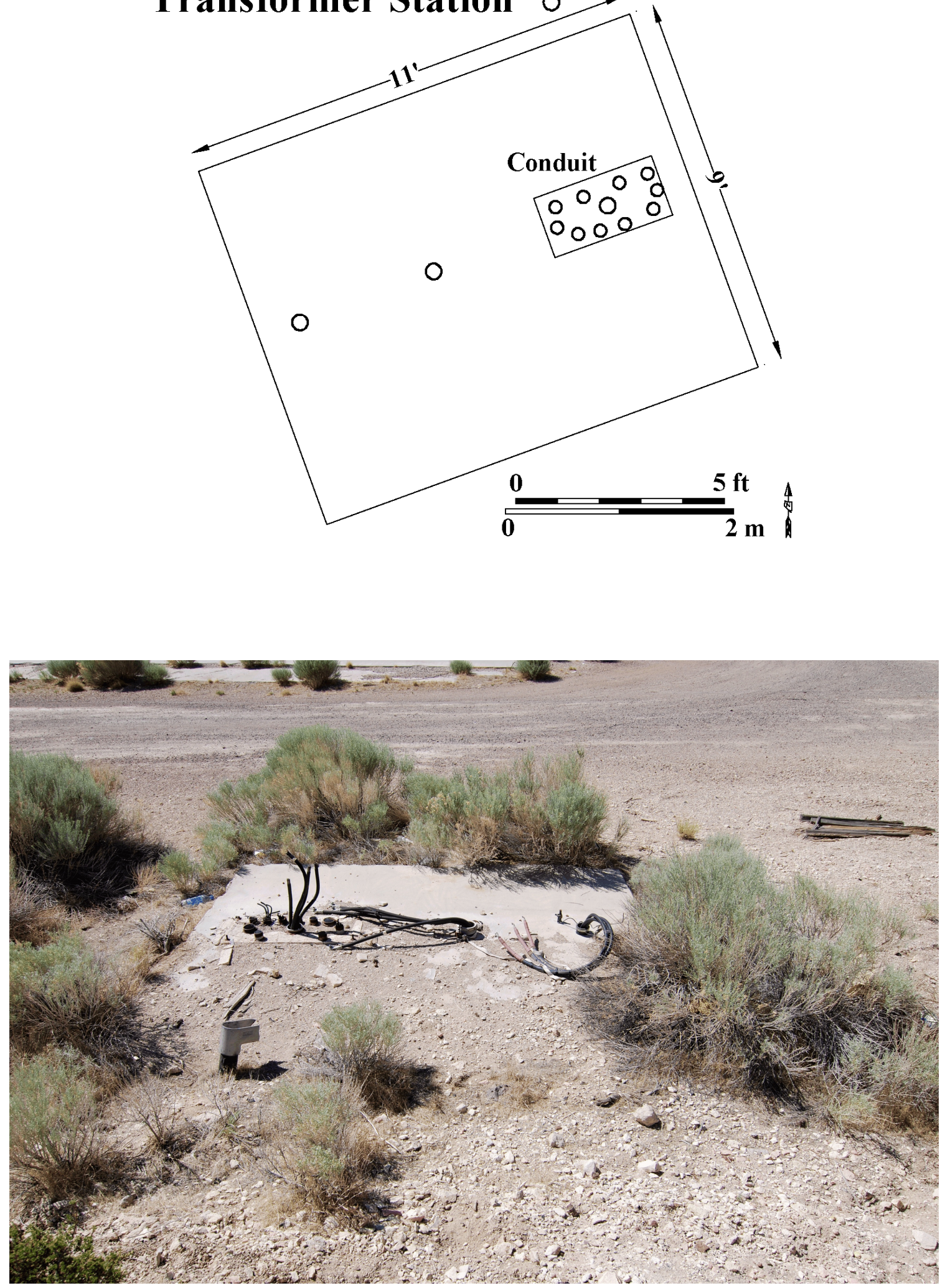

Figure 95. Plan map and photograph of Feature 36, U12t Tunnel, view southeast (2007). 

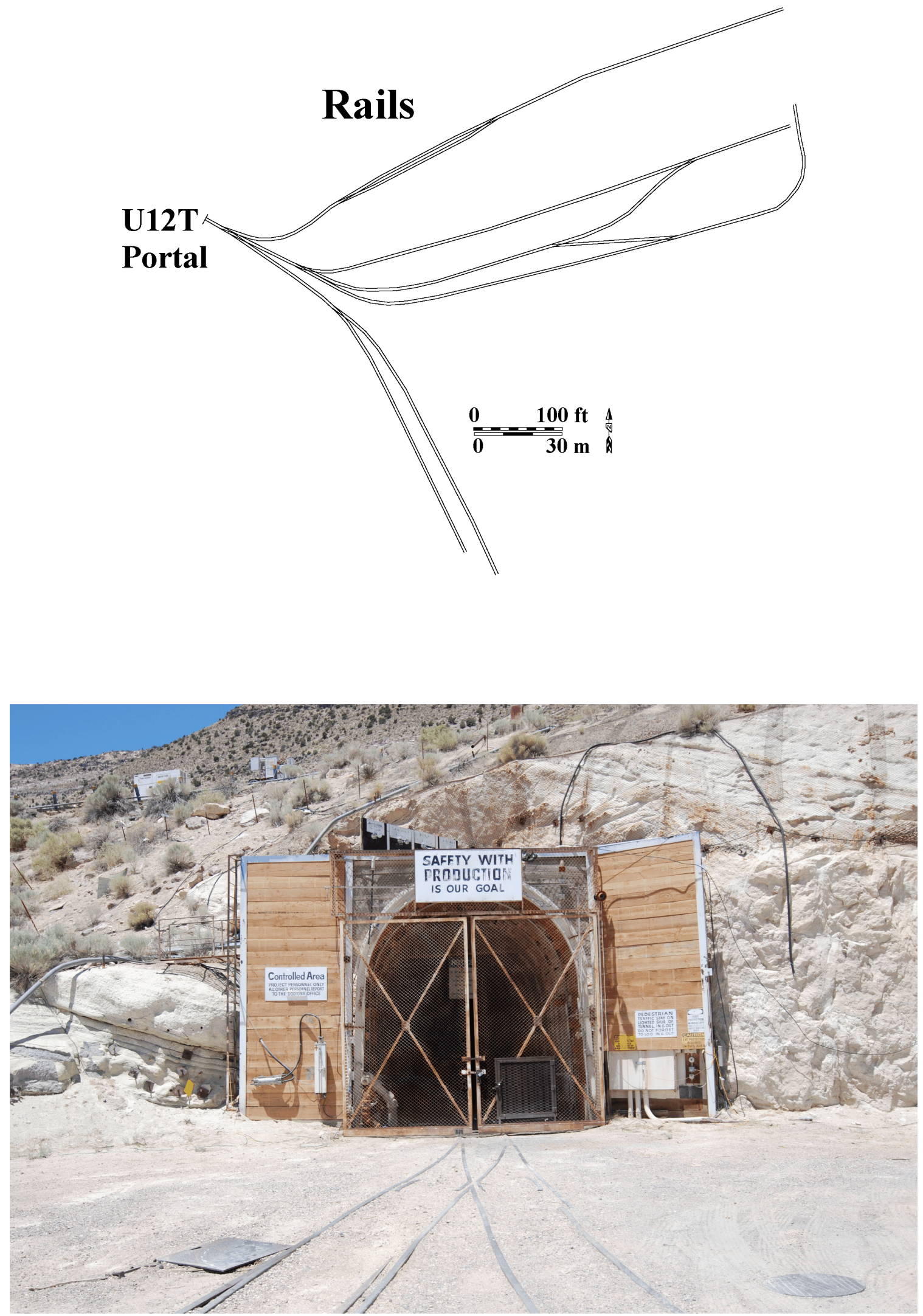

Figure 96. Plan map and photograph of Feature 37, U12t Tunnel, view northwest (2007). 
(Feature 5). Hand operated switches are at the intersection of the rail lines. Artifacts found near the rails include wire, cable, rail spikes, and metal plates.

\section{Feature 38}

Feature 38 is a fenced underground metal access plate and listed on the 1984 engineering drawing as a buried 36 inch CMP (buried and crushed) (Figure 97). The fence is 80 inches $(203.2 \mathrm{~cm}$ ) eastwest by 132 inches $(335.3 \mathrm{~cm})$ north-south and constructed of four metal T post and two strands of yellow rope. The metal plate is 48 inches north-south by 36 inches east-west and has a metal handle on the north and south ends. It is supported by concrete. No attempt was made to enter the fence or open the access plate. Artifacts near the feature are a metal saw horse, a crowbar, chain, cable, 1 inch pipe, and a 4 inch Victaulic pipe clamp.

\section{Ventilation Terrace}

The Ventilation Terrace is above the Portal Terrace and contained(s) equipment that supplied air to the tunnel during construction and testing activities. Twelve features were recorded on the Ventilation Terrace (Figure 54).

Feature 39

Feature 39 is an electrical substation (Figure 98) that consists of a locked chain-link fenced area, electrical switch panels, concrete pad, and transformer. The fenced area is $20 \mathrm{ft} 6$ inches by $20 \mathrm{ft} 6$ inches and is $8 \mathrm{ft}$ in height with three strands of barbed wire on top of the fencing. Entry is through a 40 -inch wide locked gate on the east side 54 inches $(137 \mathrm{~cm})$ from the east corner. No entry into the fenced area was attempted. Outside of the chain-link fence along the southeast side is a power backboard consisting of a metal frame $4 \mathrm{ft}$ in length and $7 \mathrm{ft}$ in height. Three switch boxes are secured to the backboard and are not labeled. Along the southwest side of the fenced area are 10 switch boxes ranging in size from $12 \times 12 \times 3$ inches to $60 \times 33 \times 12$ inches $(152.4 \times 83.8 \times 30.5$ $\mathrm{cm})$. The large boxes are labeled Buffalo \#1 and Buffalo \#2. Inside of the fenced area is a $15 \times 15$ $\mathrm{ft}$ concrete pad supporting a transformer that is approximately $72 \times 48 \times 30$ inches $(182.9 \times 121.9$ $\mathrm{x} 76.2 \mathrm{~cm})$. Five pieces of 5 inch diameter conduit are attached to the transformer. Artifacts near the feature are bolts, milled lumber, a wooden 6-ft step ladder, and conduit.

Feature 40

Feature 40 is a concrete foundation for a Buffalo Blower (Figure 99). The foundation consists of an $18 \mathrm{ft}$ east-west by $24 \mathrm{ft}(7.3 \mathrm{~m})$ north-south concrete pad and two $18 \times 18 \times 12$ inch concrete blocks. A $13 \mathrm{ft} 8$ inch $(4.2 \mathrm{~m})$ east-west by $3 \mathrm{ft} 6$ inch $(1.1 \mathrm{~m})$ rust and oil stained impression $7 \mathrm{ft}$ from the south edge of the pad locates the original position of the blower assembly. Protruding through or level with the surface of the concrete are 1 inch and $13 / 4$ inch bolts 18 inches in height, eye bolts, and 5/8 inch lead anchors for the attachment of molly bolts that secured the blower assembly to the concrete. Also, 1 inch and 5 inch diameter conduit protrudes through the concrete near the blower 

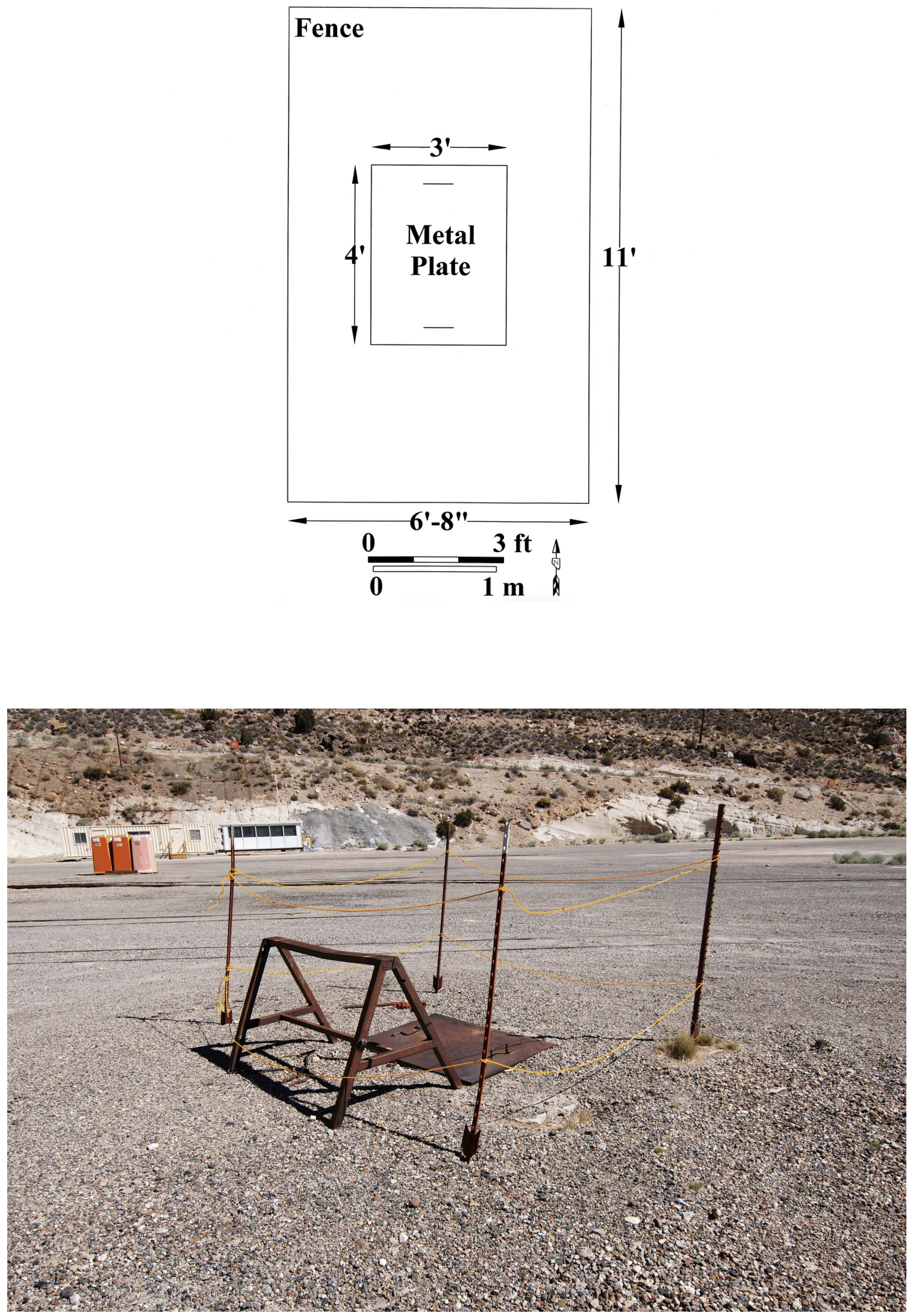

Figure 97. Plan map and photograph of Feature 38, U12t Tunnel, view northeast (2007). 

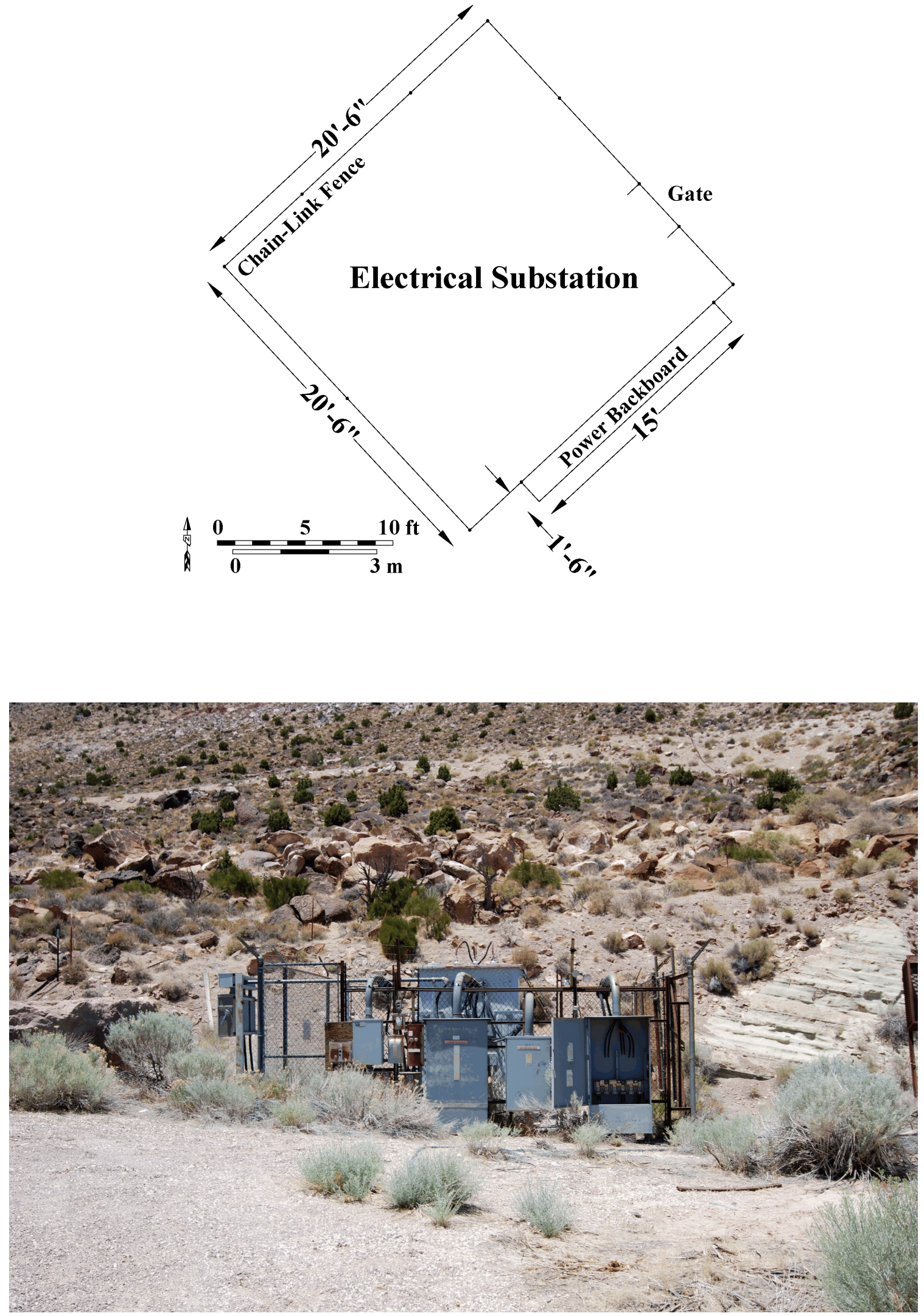

Figure 98. Plan map and photograph of Feature 39, U12t Tunnel, view northwest (2007). 

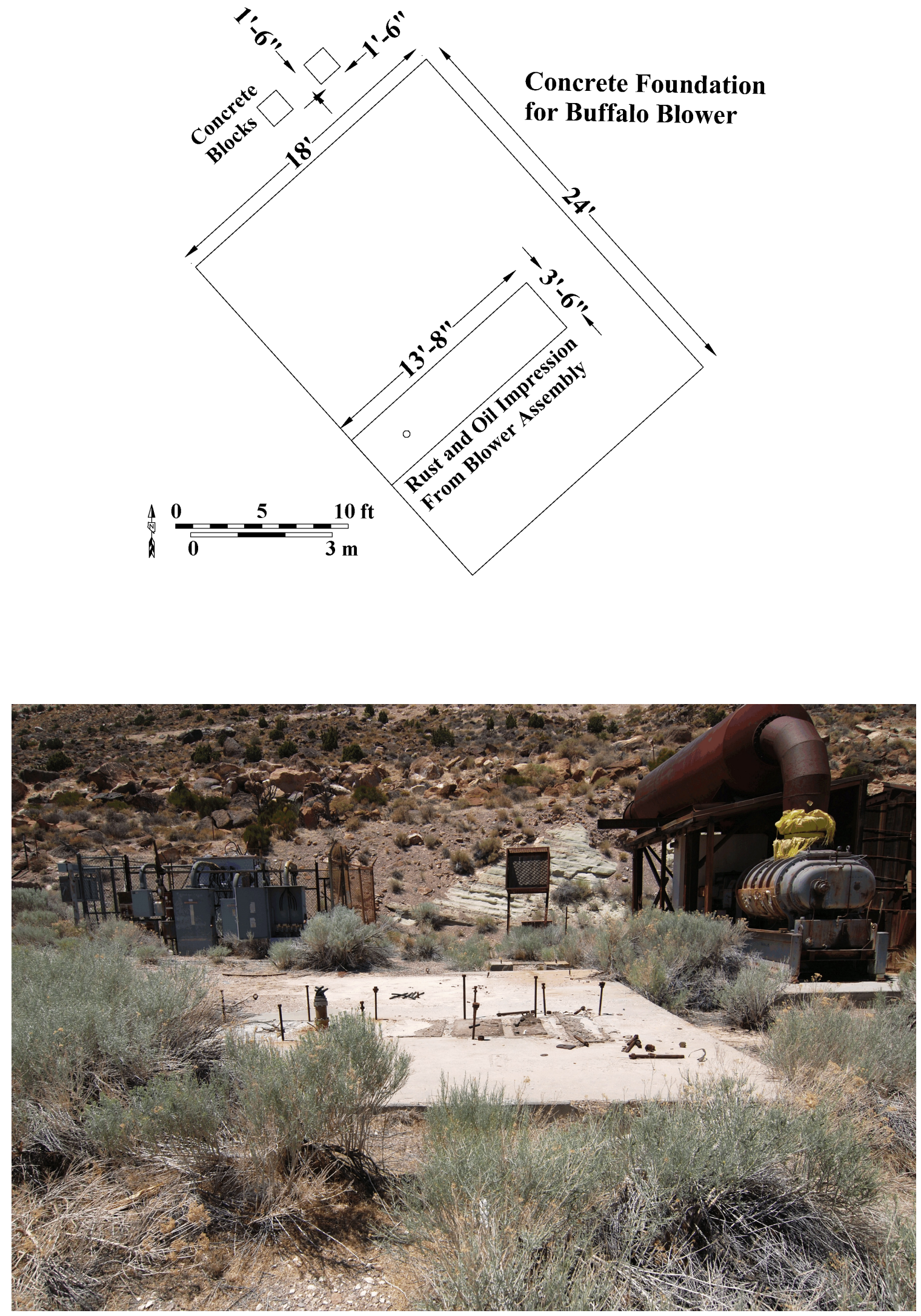

Figure 99. Plan map and photograph of Feature 40, U12t Tunnel, view northwest (2007). 
assembly impression. The concrete blocks are 36 inches north of the foundation, 48 inches from the northeast corner, and 26 inches $(66 \mathrm{~cm})$ apart (east-west). The blocks supported a roof structure above the blower (see Feature 44). Artifacts near the feature are plywood, insulated cable, bolts, nuts, washers, a saw blade, a screwdriver, a leather glove, rubber hoses, and plastic rimmed sunglasses.

\section{Feature 41}

Feature 41 is a metal and wood frame and a high voltage panel (Figure 100). The frame consists of two 3-inch angle iron legs that are set 46 inches apart (east-west) and are 126 inches $(3.2 \mathrm{~m})$ in height. On top of the legs is a 48 × 48 × 20 inch metal frame (basket) constructed of a 3 -inch angle iron frame and covered with expanded metal. The north side or back of the basket is lined with $2 \mathrm{x}$ 12 inch milled lumber. Associated with the frame is a $36 \times 30 \times 12$ inch electrical high voltage panel box labeled FEED FROM \#4. No artifacts were found near the feature.

\section{Feature 42}

Feature 42 is a Buffalo Blower (Figure 101). The feature consists of a concrete foundation, metal and wood roof and walls, and blower assembly. The foundation is $24 \mathrm{ft}$ north-south by 12 east-west. Ten feet north of the foundation are two $24 \times 24$ inch concrete blocks that support the roof and wall. Along the east side of the foundation is a metal framed plywood-covered wall that is $18 \mathrm{ft}$ northsouth and $11 \mathrm{ft}$ in height. The wall extends from the foundation to the concrete blocks to the north. On top of the wall is a north sloping $9 \mathrm{ft}$ east-west plywood covered roof attached to the wall. The wall and roof are framed with 6 inch I beam and $4 \times 6$ inch, 4 x 4 inch, and $2 \times 4$ inch milled lumber. Cross bracing is by 3 inch angle iron.

The blower assembly consists of a metal frame, electrical panel, electric motor, gear reducer, blower, and intake pipe. The frame is $18 \mathrm{ft} 3$ inches $(5.6 \mathrm{~m})$ north-south by 60 inches $(1.5 \mathrm{~m})$ east-west and is 26 inches in height. On top of the frame at the north end is an $80 \times 80 \times 20$ inch $(203.2 \times 203.2$ $\mathrm{x} 50.8 \mathrm{~cm}$ ) electrical panel box that supplies electricity to the motor. Attached to the panel is a Reliable, 17,070 rpm, 460 volt electric motor. A Western gear reducer attached to the motor is manufactured by Western Gear Corporation, Belmont, California. On the south end of the frame is the blower assembly attached to the gear reducer. It is a Sutorbilt series $3200 \mathrm{~S}$, manufactured by Fuller CO/GATX Compton, California and measures $60 \times 22$ inches $(152.4 \times 55.9 \mathrm{~cm})$. Exiting the top of the blower assembly is an exhaust pipe approximately 32 inches diameter and $8 \mathrm{ft}$ in length. The pipe forms a 90 degree bend and is attached to a larger pipe that is $5 \mathrm{ft}$ in diameter and extends $21 \mathrm{ft}$ to the north. Exiting the larger pipe is a 36-inch diameter pipe that extends $10 \mathrm{ft}$ to the north. The north end of this pipe is cut at a 45 degree angle and contains a weighted damper valve that automatically closes to prevent air from flowing back into the system (check valve). No artifacts were found near the feature. 


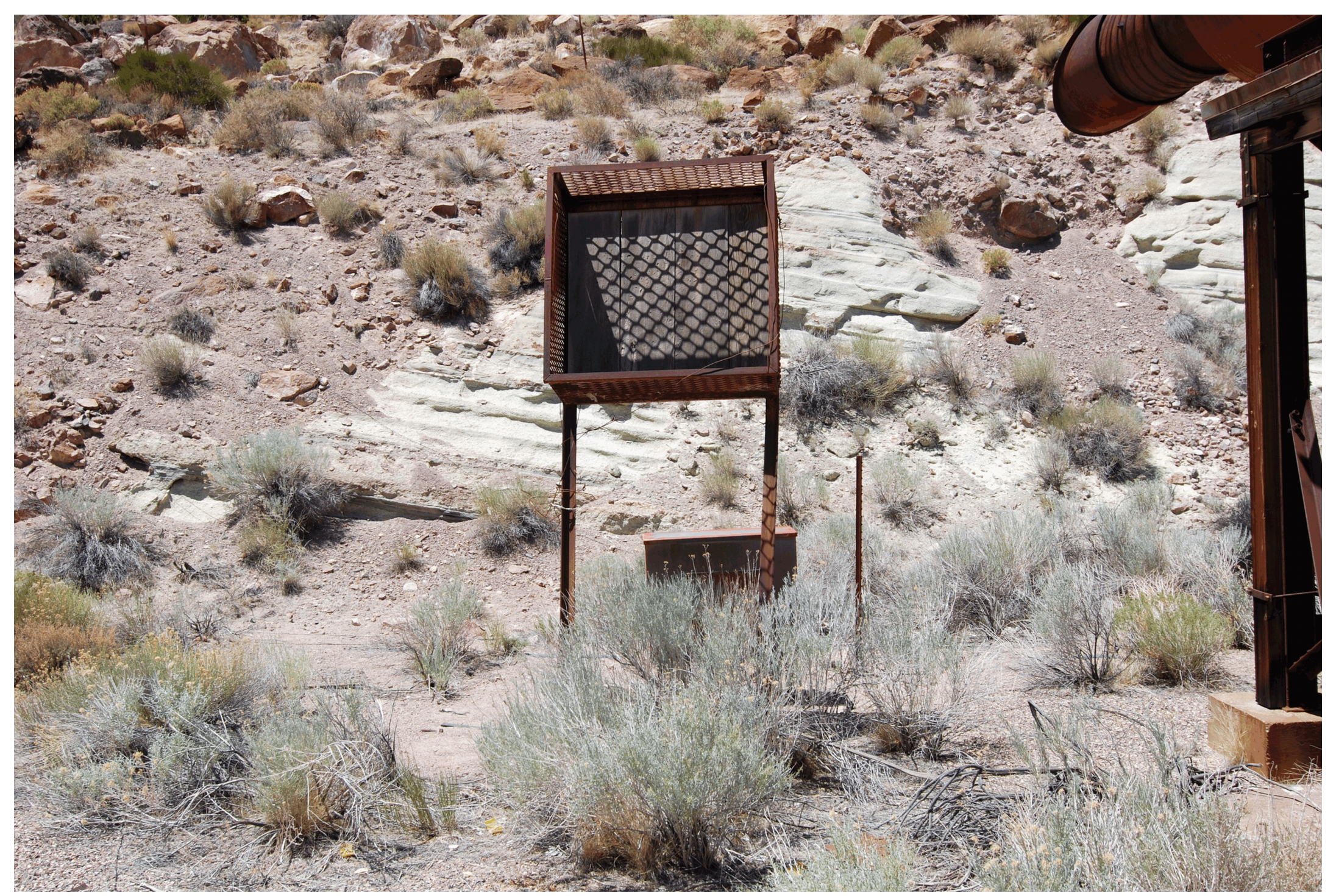

Figure 100. Photograph of Feature 41, metal and wood frame, U12t Tunnel, view north (2007). 

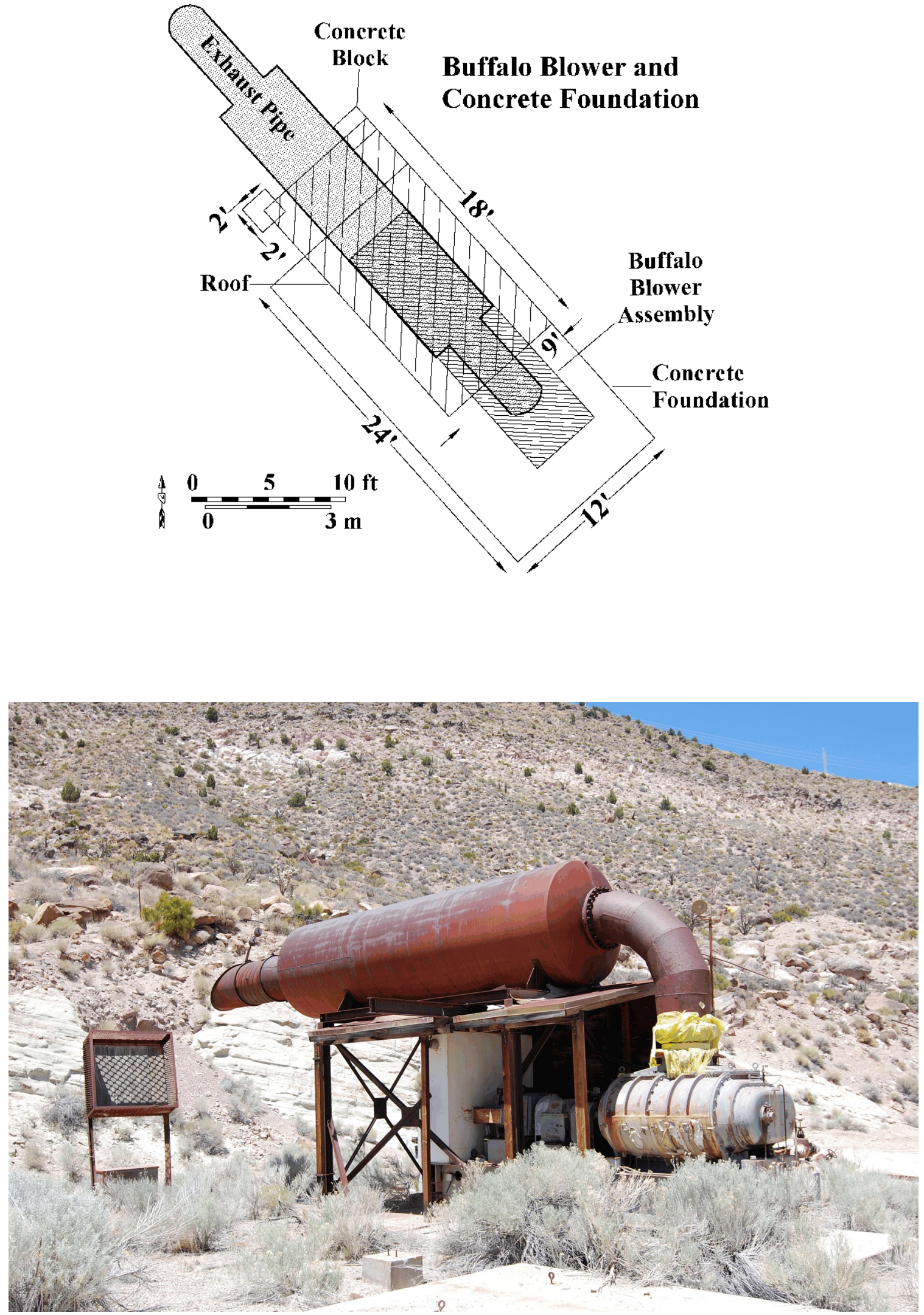

Figure 101. Plan map and photograph of Feature 42, U12t Tunnel, view north (2007). 